\title{
On the Jesuit Edition of Newton's Principia. Science and Advanced Researches in the Western Civilization
}

\author{
Paolo Bussotti ${ }^{1}$, Raffaele Pisano ${ }^{2}$ \\ ${ }^{1}$ Alexander von Humboldt Foundation, Berlin, Germany \\ ${ }^{2}$ Centre Sciences, Sociétés, Cultures Dans Leurs Évolutions, University of Lille 1, Villeneuve d'Ascq-Lille, France \\ Email: paolobussotti66@gmail.com, pisanoraffaele@iol.it
}

Received September 30 ${ }^{\text {th }}, 2013$; revised October 31 ${ }^{\text {st }}, 2013$; accepted November $8^{\text {th }}, 2013$

Copyright (C 2014 Paolo Bussotti, Raffaele Pisano. This is an open access article distributed under the Creative Commons Attribution License, which permits unrestricted use, distribution, and reproduction in any medium, provided the original work is properly cited. In accordance of the Creative Commons Attribution License all Copyrights (c) 2014 are reserved for SCIRP and the owner of the intellectual property Paolo Bussotti, Raffaele Pisano. All Copyright $@ 2014$ are guarded by law and by SCIRP as a guardian.

In this research, we present the most important characteristics of the so called and so much explored Jesuit Edition of Newton's Philosophice Naturalis Principia Mathematica edited by Thomas Le Seur and François Jacquier in the 1739-1742. The edition, densely annotated by the commentators (the notes and the comments are longer than Newton's text itself) is a very treasure concerning Newton's ideas and his heritage, e.g., Newton's geometry and mathematical physics. Conspicuous pieces of information as to history of physics, history of mathematics and epistemology can be drawn from it. This paper opens a series of study concerning Jesuit Edition, whose final scope is to put in evidence all the conceptual aspects of such edition and its role inside the spread of scientific ideas and inside the complex relation science, popularization \& society.

Keywords: Newton; Principia’s Jesuit Edition; La Seur; Jacquier; Calandrini; Mathematical Physics; History of Mathematics; History of Physics; History of Astronomy; Popularization

\section{An Outline}

With regard to Newton literature, a premise is necessary: a systematic and very good work exists on this subject, Wallis and Wallis (Wallis \& Wallis, 1977). This text is an indispensable and complete reference point up to 1975. Therefore, in our bibliographical indications, we will refer only to those publications concerning Newton and published before 1975 we consider particularly important. Instead, we will try to be more specific as to works published after 1975. Here we mention the most important editions of the Principia: first edition 1687 (Newton, 1687). The second edition was published in 1713 (Newton, 1713). It contained the general Scholium and a more complete theory of the moon, of the equinoxes and of the comets. The second edition was reprinted one year later in Amsterdam (Newton, 1714) and the text was corrected according to the Corrigenda. In 1723 the second edition was reprinted in Amsterdam including some mathematical papers, among them the Enumeratio linearum tertii ordinis. Newton (1726), third edition: new explanations in the second book as to the resistance in the fluids. In the third book, clearer explanations on the fact that gravity is responsible for the lunar orbit. New observations on Jupiter and on the comets. In 1729, Motte translated into English the second edition. See Newton (1713-1729). In 1739 the first volume of the so called Jesuit Edition was printed ([1726] [1739-1742], 1822; 1760). There are the historical editions of the Principia. There are several modern editions. Among them the most important is maybe the reprint of the third edition (Newton, 1972) edited by Bernard Cohen (1914-
2003) and Alexandre Koyré (1892-1964; see also Koyré, 1965).

\section{Science and Society: Newton's Principia in the $17^{\text {th }}-18^{\text {th }}$ Century}

The events and popularization connected to Newton's science in his Philosophice Naturalis Principia Mathematica (hereafter Principia), to the publication of the book, and to the reactions of the scholars (not only physicists and mathematicians, but also philosophers and men of letters) are linked to a complex series of facts which show the deep interconnections between Newton's life and personality, cultural-scientific and social context of the late $17^{\text {th }}$ century and development of physics - in particular-and European society—in general-in the $18^{\text {th }}$ century: Mainly:

1) As to Newton biography, it is possible to identify a period of about 18 months (between 1665 and 1667) that was decisive for almost all his most important discoveries. In the summer of 1665 the Trinity College, where Newton had become bachelor in April 1665, was closed because of a plague. Newton came back to his native manor of Woolsthorpe, where, for 18 months, he dedicated almost exclusively to develop his scientific ideas. The method of fluxions, the optical experiments and discoveries, the basis of the theory of gravitation were discovered in those months. Furthermore Newton had the chance to rethink of the results obtained by Johannes Kepler (1571-1630), Galileo Galilei (1564-1642), René Descartes (1596-1650), Thomas Hobbes (1588-1679), Pierre Gassendi (1592-1655) and Robert 
Boyle (1627-1691), authors he had studied during his permanence at the Trinity College, but whose results and methods he examined closely in those 18 months. Almost all Newton's subsequent achievements were an extension and a refinement of the intense work carried out in those 18 months spent in Woolsthorpe.

2) The scientific context in which Newton worked is strictly connected to the social-economical one. Three traditions converged in the Principia:

a) Astronomy. For Newton, a fundamental reference point was Kepler. However Newton exploited the results, and above all the observations, of many astronomers lived before and after Kepler. The observations of those lived after Kepler were particularly important because they offered a new and precise material on which Newton could prove the validity of his theories. Specifically the following ones have to be mentioned: Godefroy Wendelin (1580-1667), Johann Baptist Cysat (1587-1657) Richard Norwood (1590-1675), Giovanni Riccioli (1598-1671), Giovanni Alfonso Borelli (1608-1679), Johannes Hevelius (1611-1687), Jeremiah Horrocks (1618-1641), Jean Picard (1620-1682), Nicholas Mercator (1620-1687), Valentin Stancel (1621-1715), Adrien Auzout (1622-1691), Giovanni Domenico Cassini (1625-1712), Jean Richer (1630-1696), Marco Antonio Cellio ( $17^{\text {th }}$ century, he was an optician, too), Samuel Colepresse $\left(17^{\text {th }}\right.$ century), Egidio Francesco Gottignies (1630-1689), Geminiano Montanari (1632-1687) Claude Antoine Couplet (1642-1722), John Flamsteed (1646-1719), Edmund Halley (1656-1742), Louis Feuillée (1660-1732), Giacomo Cassini (1677-1736), Charles Hayes (1678-1760). In the third book of the third edition of the Principia (1726) all these astronomers, their results, and (especially) their observations are quoted. They were exploited by Newton to have a precise idea of the intensity of gravity at different latitudes, of the moon position and of the planetary paths. They were important also for the tides-theory. All these arguments were dealt with in the third book. It is interesting to note that many of the observations carried out by these astronomers were possible only in the context of the technical and social developments of the last 70 years of the $17^{\text {th }}$ century, not before. From a technical point of view, it is known that the telescopes got substantial improvements in this period, as to magnification and clearness of the produced imagine. This depended on a better theoretical knowledge of the refraction-phenomena, by an improvement in the researches on lenses and mirrors and by a better grinding-technique. Optiks ${ }^{1}$, and in particular applied optics (Newton, as well known, gave fundamental contributions both to theoretical and applied optics) was becoming an important science from a social point of view. Good spy-glasses were required by the navies and the armies of the most important countries and they had significant civilian uses, too. This brought to quick improvements, so that the telescopes available in the second half of the $17^{\text {th }}$ century were not comparable with the telescopes used by Galileo and Kepler (Pisano \& Bussotti, 2012). The consequence was that far better observations were available and could be exploited by a genius as Newton. In addition to that, it is necessary to underline that in the second half of the $17^{\text {th }}$ century, the most powerful countries sent their experts (and in particular astronomers, and many of the above mentioned ones) to exotic regions in order to calculate the lengths of meridian arches and to measure the time of the pendulum oscillations at

\footnotetext{
${ }^{1}$ Recently see Darrigol, 2012.
}

different latitudes. This was perfectly coherent with the logic of a complete control of space and time-to obtain with the help of scientific means and, hence, of the scientists - that was imposing in the European society and politics. As a consequence the scientists acquired a new prestigious official social status and many data became available for theoretical researches, too, as Newton's.

b) Physics: physics, in the modern sense of the term, was a new science. Differently than astronomy, the ancient tradition in physics (considering both Aristotelian physics and impetus theory) had no utility for Newton's aims. A part from Galileo, in the Principia Newton mentions almost exclusively Huygens' (1629-1695) results. He also exploited astronomical observations carried out by Huygens, but basically Newton discusses Huygens' ideas and results on the gravity force. Another author whose researches are quoted and used by Newton is Christopher Wren (1632-1723). As know, Newton's relations with Robert Hooke (1635-1703) were rather controversial. Finally, the Principia can also be read as the book in which a decisive critics is moved against Descartesian physics (Bussotti and Pisano 2013), that was getting many adherents in the continental Europe. If theoretical physics was a science whose bases were uncertain before Newton's works, in the $16^{\text {th }}$ and in the first half of the $17^{\text {th }}$ centuries many studies were developed in statics, ballistics, pneumatics and constructions of machineries (without considering optics). Only to mention the most important authors let us remember Niccolò Tartaglia (1499-1557), Giovanni Battista Benedetti (1530-1590), Simon Stevin (15481620), Otto von Guericke (1602-1686), Blaise Pascal (16231662), Robert Boyle (1627-1691) and mathematicians-engineers (see Pisano's works) like Mariano di Iacopo called Taccola (1382-1458?), Leon Battista, Alberti (1404-1472), Francesco di Giorgio Martini (1439-1502), Vannoccio Biringuccio (1480-1539?), Antonio da Sangallo il Giovane (1483-1546) Francesco de' Marchi (1504-1576), Daniele Barbaro (15131570), Girolamo Maggi (1523-1572), Camillo Agrippa (14861535), Buonaiuto Lorini (1540-1611), Domenico Fontana (1543-1607), Galasso Alghisi da Carpi (1523-1573) etc.; and of course Leonardo da Vinci (1452-1519). The perspective in which Newton wrote the Principia was theoretical, but he did not forget to mention the practical consequences his research could have. In this sense the corollary II to the three laws (Newton, 1822: I, pp. 19-22) is extremely significant because Newton shows that, by the three laws and the decompositions of forces, all the problems concerning the functioning of the simple machines can be-in principle-solved in a uniform and general way. In the case of the development of physics, too, the relationship science and society are strong: starting from the beginning of the $16^{\text {th }}$ century the passage from the world of approximation to the universe of precision induced and at the same time was inducted-in a situation of feed-back - by the work of the physicists and engineering who achieved quick improvements in the construction-machineries technique. The complex social transformations that brought to the geographical discoveries, to the technical improvements and-at least in a part of Europe-to a first stage of capitalistic economy were joined to a conceptually reach, but is a sense, disordered development of studies connected with physics and, in particular, to mechanics. One of the many aspects of Newton's Principia is that this phase connoting physics in the $16^{\text {th }}$ and first half of the $17^{\text {th }}$ century can be considered-at least from a theoretical point of view-concluded. With the Principia we are in pres- 
ence of a rare case in which a book is both foundational and inventive: foundational, because all the known results in mechanics were inserted in a new frame based on few principles and laws; innovative, because most part of the discoveries exposed in the Principia were unknown at all ${ }^{2}$.

c) Geometry and calculus. The two fundamental aspects of the mathematics in the Principia were: 1) theory of conic sections; 2) the particular way in which Newton introduced infinitesimal reasonings, always basing them on a geometrical support. With regard to conics sections, Apollonius was a direct reference point and, among the modern mathematicians who dealt with this subject, Newton quotes Philippe De la Hire (1640-1718). With regard to the use made by Newton of infinitesimal procedures in the Principia we refer to the literature and to this work itself.

Here we refer the Principia published ${ }^{3}$ in the 1687. As known, the book was successful: England was already the most advanced country in Europe and, despite the great difficulties of the text, Newton's work was recognized as a revolutionary contribution to science and it became famous also among scholars who were not physicians or mathematicians. The case of John Locke is famous. Scholars who criticized some aspects of Newton's thought, could not anyway avoid to recognize the significance of his work. In the continental Europe, the situation was a little bit different because the persistency of Descartesian physics was more lasting. Nevertheless the scholars who aimed to obtain concrete results in physics followed New-

${ }^{2}$ With regard to Newton's biography, we limit to mention the fundamental Westfall (1983, 1995). For sake of brevity and without pretension to be exhaustive-as done in this section-we suggest the following accredited secondary literatures on scientific civilizing, science in society and on the spread of Principia and of Newtonianism in Europe in the $18^{\text {th }}$ century: Agassi (1978), Agostino (1988), Ahnert (2004), Allen (1998), Arthur (1995) Axtell (1965), Baillon (2004), Barber (1979), Barker (2006), Beaver (1987), Berggren and Goldsein (1987), Biagioli (1998, 1999), Blay (1983), Boss (1972), Bourdieu (1975, 1999), Bricker and Hughes (1990), Briggs (1983), Brockliss (1992), Buchwald, Feingold (2011), Bussotti and Pisano (2013), Calinger (1968), Calinger (1969), Casini (1988), Champion (1999), Clark (1992), Clark (1997), Clark, Golinski and Schaffer (1997), Cohen (1990), Craig (1963), Crasta (1989), Coudert (1999), Cunningham and Williams (1993), Dear (1987, 1995, 1998), Ducheyne (2005), Durham and Purrington (1990), Elliott (2000), Fara and Money (2004), Feingold (2004), Fellmann (1988), Ferrone (1982), Force (1983, 1985, 2004), Force \& Hutton, (2004), Friesen (2006), Gascoigne (1988), Gaukroger (1986), Goldish (1998), Goldish (1999), Golinski J (1998), Guerlac (1981), Guerrini (1985), Hall (1978), Hampson (1981), Hankins (1990), Harman (1988), Harrison (1995), Haycock (2004), Heidarzadeh (2006), Heimann, McGuire (1971), Henry (1992), Hessen (1931), Hutton (2004a), Hutton (2004b), Iliffe (2004), Iltis (1977), Jackson (1994), Jacob (1976), Jacob (1977), Jacob (1978), KingHele \& Rupert Hall (1988), Leshem A (2003), Lord (2000), Lüthy (2000), Lynn (1997), Malet (1990), Mandelbrote (2004a), Mandelbrote (2004b), Marcialis (1989), Markley (1999), Mazzotti (2004), McMullin (1978), Montgomery (2000), Munby (1952), Osler (2004), Pagden (1988), Pater (1994), Phemister (1993), Phillipson (1981), Porter (1981), Porter and Teich (1992), Pulte, Mandelbrote (2011), Purrington and Durham (1990), Rattansi (1981), Rousseau and Porter (1980), Ruderman (1997), Rupert Hall (1999), Schama (1981), Smolinski (1999), Snobelen (1997), Snobelen (2004), Stewart (1992), Stewart (2004), Taylor (1981), Teich (1981), Thijssen (1992), Wall (2004), Westfall (1958), Westfall (1971), Whaley (1981), Wigelsworth (2003), Yolton (1994), Young (2004), Zambelli (1978), Zinsser (2001).

${ }^{3}$ In effect, the book was presented at The Royal Society of London for Improving Natural Knowledge (briefly known as The Royal Society) in April, 28, 1686, and only in-between May, 19 and June, 30 The Royal Society firstly approved and then licensed by Pepys (President of The Royal Society) to publish it. Subsequently Edmond Halley (1656-1742) received the Book II and Book III respectively in March, 1, 1687 and in April, 11, 1687. The first edition, completed of the three volumes into Latin language, were published in July, 5, 1687. ton's achievements and made them wider. Once again, most part of the researches in physics were carried out by scholars living in advanced countries from a social and economical point of view: only to limit to the scientists lived between the $17^{\text {th }}$ and the $18^{\text {th }}$ centuries: the Bernoulli family and Jacob Hermann (1678-1733) in Swizerland, Pierre Varignon (1654-1722) and de L'Hopital (1661-1704) in France, Willem Jacob's Gravesande (1688-1742) in Holland, David Gregory (1659-1708), Abraham de Moivre (1667-1754), John Keill (1671-1721), Stirling (1692-1770), Colin McLaurin (1698-1759) in Great Britain, only to mention the most famous and to limit to physics. However, rapidly after the publication of the first edition, there was a development of mathematical technique: the structure of the reasoning used to prove the theorems and to solve the problems changed in respect to Newton. The geometrical-analytical methods by Newton were progressively replaced by analytical procedures. Therefore, starting from about the 30s of the 18th century, the results of Newton were kept and made wider, but his methods progressively disappeared and became difficult to be fully understood. This is the most important reason why, after the third edition, a series of commentaries on the Principia were published ${ }^{4}$. Inside this kind of literature the so wrongly called Jesuit Edition (Newton, 1726, 1739-1742, 1822 hereafter Newton 1822, and also abbreviated with JE), of the Principia, a reprint of the third edition, deserve a particular place at all. With its huge and systematic apparatus of notes to every single Newton's proposition it represents a fundamental support to understand Newton's mathematical technique, physical approach and methodology. The incipit of the Monitum written by the commentators represents a clarifying introduction to their work because they wrote:

All who had heard even only the name of the very famous author knew how secret and at the same time useful the doctrines exposed in the Philosophiae Naturalis Principia Mathematica are. The dignity and the sharpness of the subject, the more than geometric brevity of the reasoning are so conspicuous that that magnificent work looks written only for a very little number of expert geometers ${ }^{5}$.

As above mentioned, the tradition of the commentaries to the Principia is long and dates back to the first years after the publication of Newton's work (1687) until reaching some of the most modern researches on Newton ${ }^{6}$. In general all the commentators:

1) Try to explain Newton's propositions in a clearer manner than Newton did;

${ }^{4}$ For sake of brevity we only refer some of the most important of them relative to the all Principia or to conspicuous part of them, because the number of commentaries and notes on single propositions or themes dealt with in the Principia is so huge that it is impossible to provide even an idea in this paper: Keill (1701); Gregory (1702); Whiston (1707); Desaguliers (1717); 's Gravesande (1720-1721); Pemberton (1728); Clarke (1730, 1972); McLaurin (1748, 1971); Du Châtelet (1756-1759). Translation into French and commentary of the Principia. See also Zinsser (2001); Wright (1833). Wright is the same mathematician that edited the Glasgow version of JE. His commentary, in two books, is fundamental for the research on Newton and his mathematical technique in the Principia; Chandrasekhar (1995); Cohen (in Newton, 1999). A synthetic, but informative, overview on this subject is Zinsser (2003).

${ }^{5}$ Newton, 1822: I, p. VII, lines 1-6. (The translations is ours).

${ }^{6}$ We do not comment the development of mathematics in mechanics until the birth of modern science, e.g. Leonardo da Vinci, Tartaglia, Descartes, Galileo, Newton, etc. On that see: Pisano, 2013; Pisano \& Bussotti, 2012; Pisano 2013b; Pisano \& Bussotti, 2013; Pisano, 2011; Pisano, 2007; Capecchi \& Pisano, 2014; Pisano, 2013c. 


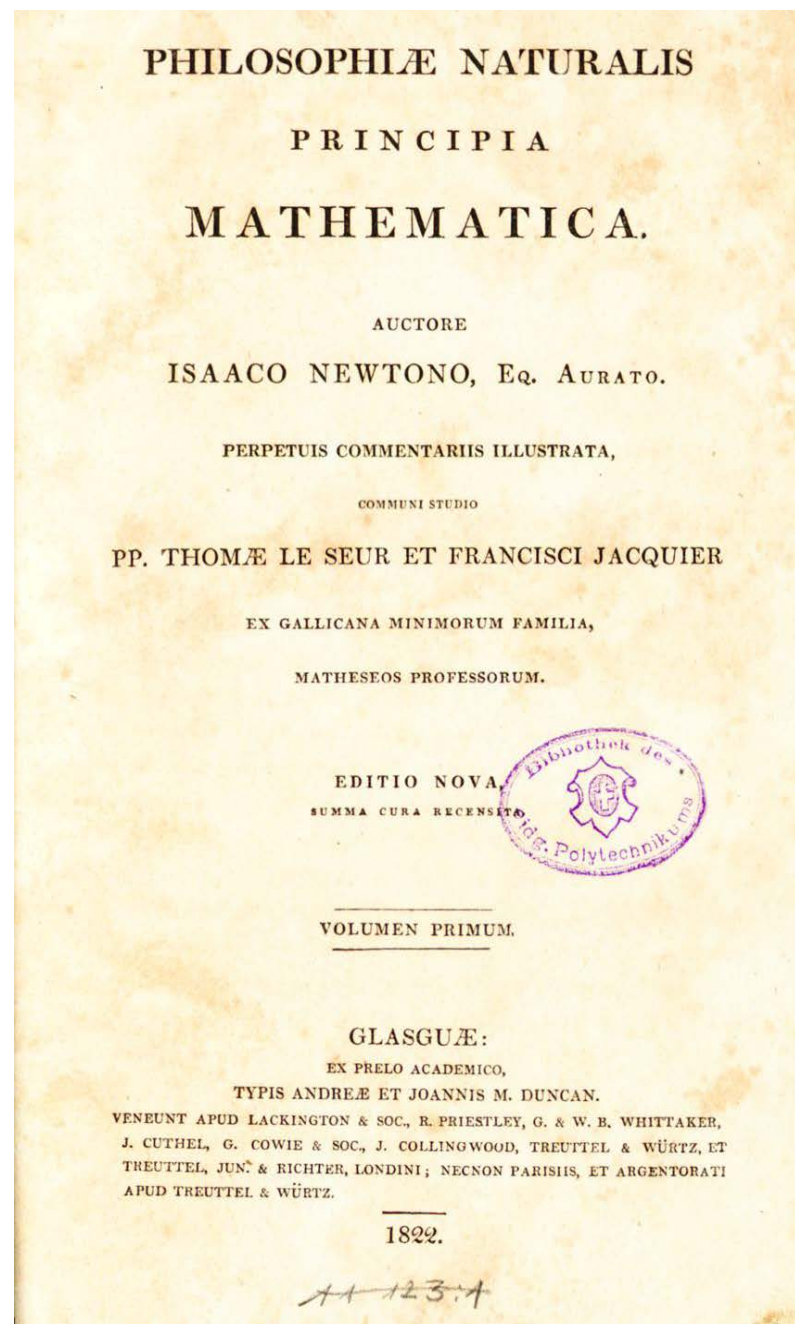

(a)

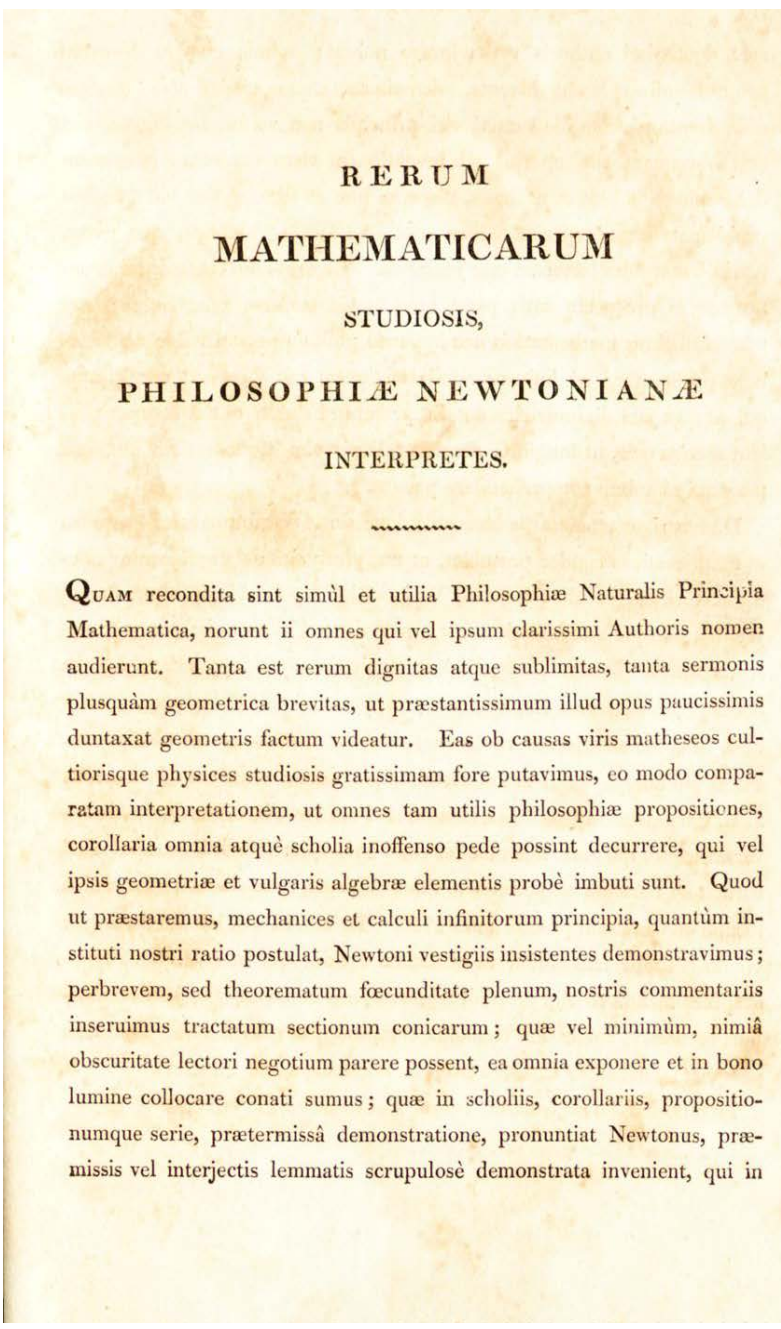

(b)

Figure 1.

(a) Frontispiece of the Glasgow Edition ${ }^{7}$; (b) Incipit of the Monitum written by the commentators ${ }^{8}$.

2) Translate the properties given by Newton geometrically in more analytical terms;

3) Sometimes explain the development of physics, based on Newton's discoveries, after Newton.

Some of these commentaries are detailed, but no one is as detailed as the JE and presented as single notes to Newton's propositions.

The scopes of the commentators is clear starting from their initial sentence (see Figure 1, right side), they claim that the Principia are a difficult book because of the dignity and subtility of the subject dealt with (Newton, 1822: I, Incipit of the Monitum, p. vi, line 3). However this is not the sole difficulty connected to the way in which Isaac Newton (1642-1727) carried out his research. He used the geometrica brevitas (Newton, 1822: I, p. vi, line 4) that is his demonstrations are in general based on geometrical classical reasoning: after having reached a certain result, Newton needs instantaneous quantities and because of this he operates a passage to limit, but this happens after a series of steps based on the geometry of the figure con-

${ }^{7}$ Newton, 1822: I, p. VII.

${ }^{8}$ Newton, 1822. sidered. The calculus is fundamental, but it is often applied in the last phase of a geometrical reasoning. The geometry obviously plays a decisive role in the Principia, particularly with as the relations between geometry and calculus:

The reason why Newton, in his Principia, used the formalism of fluxions theory and the concept of fluxion itself in a sporadic and local way (at least explicitly) has been often discussed. I have already indicated that, in my opinion, this is the essential reason: so as Newton developed it in the period 1664-1671, the formalism of the theory of fluxions was not suitable to express both the direction of velocities and forces and the scalar components of forces. However, it is certain that there are other, so to say more extrinsic, reasons, too, that convinced Newton to avoid the trouble of looking for a convenient extension of the formalism so that it can be used in mechanics ${ }^{9}$.

After the publication of Newton's work-beginning with Pierre Varignon (1654-1722), Jakob Bernoulli (1654-1705), David Gregory (1659-1708), Johann Bernoulli (1667-1748), 
John Keill (1671-1721), Jacob Hermann (1678-1733), to continue with Daniel Bernoulli (1700-1782) and Leonhard Euler ${ }^{10}$ (1707-1783), only to mention the most important mathematicians and physicists - the transcription of his results into completely analytical terms ${ }^{11}$ was a long process that permitted to better understand Newton's results and, as know, to obtain a series of further more general and extended results than Newton's. Nevertheless the difficulties in understanding the direct work of the English physicist persisted because of his mixed geometrical-analytical approach and because many demonstrations in his Principia are only outlined and are far from being complete. Therefore, the commentators had the aim to specify and clarify not only Newton's results, but more than this, Newton's methods in every detail. The consequence was that the global apparatus of notes is more extended than Newton's text itself. Therefore, the JE provides three fundamental pieces of information useful to:

1) Understand Newton's mathematical technique and physical results;

2) Get a clear idea of the development of physics and mathematical analysis in the 20 - 25 years after the publication of the third edition of the Principia (1726) because many results and, sometimes, the works of the most important physicists and astronomers are reported in the notes;

3) Fully realize the profound difference between Newton's physical-mathematical approach and the approaches of his successors.

\section{An Introduction to Principia's Jesuit Edition}

The publication of JE dates to the years 1739-1742 (Newton 1739-1742). The published edition is divided into four volume:

1739. The first volume. It includes the first book of the Principia;

1740. The second volume. It includes the second book of the Principia;

1742. The third volume. It includes the initial 24 propositions of the third book of the Principia;

1742. The fourth volume includes the propositions XXVXLII, third book and General scholium.

Thomas Le Seur (1703-1770) and François Jacquier (17111788) are the two commentators and they are mainly mathematicians. They were not Jesuits, but belonged to the "Gallicana Minimorum Familia” (Newton, 1822, Frontispiece), that is they were Minim Friars. Both of them were French. Basically they are known because of the JE, but they also wrote other essays, e.g., Elémens du calcul integral (Le Seur \& Jacquier, 1768), Riflessioni de' Padri Tommaso Le Seur, Francesco Jacquier de el' Ordine de' Minimi, e Ruggiero Giuseppe Boscovich della Compagnia di Gesù sopra alcune difficoltà spettanti $i$ danni, $e$ risarcimenti della cupola di S. Pietro (Le Seur, Jacquier, \& Boscovich, 1743) and the Elementi di perspettiva, secondo $i$ principii di Brook Taylor con varie aggiunte spettanti all'ottica e alla geometria (Jacquier, 1755).

For the JE (Newton, 1726, 1739-1742, 1822) the contributions of the Swiss scientist Jean-Louis Calandrini (1703-1758) were fundamental. He organized and financed the edition. Fur-

\footnotetext{
${ }^{10}$ Particularly from Newton's mechanics to Euler's equations see Darrigol 2005.

${ }^{11}$ This process can be considered as completed with Joseph-Louis Lagrange's (1736-1813) Mécanique Analitique (1788). See Pisano, 2013a; Pisano \& Capecchi, 2013.
}

thermore, inside the edition, many of the most important notes and comments are written by Calandrini himself. Le Seur and Jacquier are explicit at all in this sense: in the Monitum at the first volume, Le Seur and Jacquier spoke of Calandrini as "versatissimus in rebus mathematicis [very expert in mathematics]" and as the person who adorned and edited the edition in a very elegant manner (Newton, 1822: I, p. viii, lines 21-25). Calandrini is also mentioned in the Monitum premised to the second volume. He is eulogized for the care and attention with which he controlled the publication of the second volume (Newton, 1822: II, Monitum, one page without number, lines 16-20). Calandrini is also quoted in the Monitum to the third volume (Newton, 1822: III, Monitum, one page without number, lines 9-13). Here Le Seur and Jacquier wrote that they cannot thank enough Calandrini for the contributions and the benefits he has given to the edition. The notes of Calandrini can be recognized because they are indicated by an asterisk. In the Editoris Monitum at the beginning of the third volume, the editor (that is Calandrini) explains that, in the fourth volume, he will avoid the asterisk because the distinction between his notes and the ones by Le Seur and Jacquier has been interpreted by someone as a critic of his to the notes-apparatus written by the two mathematicians, while it was not the case. On the other hand, in the same Editoris Monitum we read that, in the fourth volume, he hopes Newton's Lunar theory and the difficult connected calculations will be made clear with the help of the notes (Newton, 1822: III, Editoris Monitum, one page without number, lines 11-15). These words make it likely that the notes and addictions to Newton's lunar theory are due to Calandrini. Furthermore, in contradiction to what Calandrini had written in the Editoris Monitum of the third volume, the asterisks are present. Hence the notes by Calandrini (and they are the majority as to the third book of Principia) can still be recognized.

The second edition of JE was printed in Colonia Allobrogum (Geneva) in 1760 by the publishing house Cl. and An. Philibert. This edition corrects some mistakes (especially print-mistakes) of the first edition. It is in three volumes corresponding to the three books of the Principia (Newton, 1760).

The third edition dates back to 1822 and was published in Glasgow by the publishers Andrew and John Duncan (Newton, 1822). This edition, in four volumes as the original one, is very important because the editors analysed in depth the two previous editions, compared them and emendated them, where necessary, eliminating some mistakes present in the two editions published in the $18^{\text {th }}$ century. The mathematician who realized this hard work was John Wright, who examined in detail both the $18^{\text {th }}$-century editions. We have analysed this edition and the quotations and the imagines are drawn from it (Ibidem).

\section{The Structure of the Paper}

This article is an overview of an extended research we are carrying out on the JE. Despite this edition is celebrated because of the explicative notes added by the commentators, it is not so much directly commented by secondary literature. Thus in order to offer a precise historical and epistemological panorama, our research concerns the reception, the influence and the spread of Newton's ideas in the period between the publication of the first edition of the Principia (1687) and the half of the $18^{\text {th }}$ century. It is possible to summarize these kinds of studies into three categories:

a) Editions of the Principia translated into various languages 
and commentaries directly tied to Newton's text;

b) Studies dedicated to the way in which advanced physicsin all its aspects-was influenced by the Principia and to the manner in which Newton's physical results and mathematical methods were considered in England and in the continental Europe;

c) Studies inherent to the way in which the Principia influenced the cultural environments at the end of the $17^{\text {th }}$ and in the $18^{\text {th }}$ century.

In this complex context, it is needed to clarify the scopes of our work. They are:

1) To clarify the nature, the purposes and the structure of the notes added by the commentators to Newton's text ${ }^{12}$. The enquire on the notes will be a useful guide to understand the relevance of the specific mathematical methods used by Newton inside his physics. Therefore a mathematical analysis of the most important notes is necessary as well as a comparison between the methods the commentators used to prove or to clarify some theorems by Newton and the methods used by other authors, lived before them or in their same epoch;

2) To verify the hypothesis that the relationship between physics and mathematics changed in the dense period between 1687 (year of publication of the first edition of the Principia) and the publication of the JE and to understand how physics itself changed in this period. The notes of the commentators of the JE are fundamental for this purpose because they often present the development in physics due to the greatest physicists and mathematicians of that period;

3) To reconstruct the social environment in which the Jesuit
Edition was conceived and developed;

4) To present the structure of a series of texts that could be called physical-mathematical commentaries to Newton's Principia and that reached their most complete expression in the JE.

A series of papers will be published in which we will present the development of the research, whose final aim is the publication of a book on this subject. This structural paper consists of the following sections:

a) General view on the JE: the editors and the various editions;

b) General view on the Jesuit Edition: the content;

c) Specific analysis of the initial six sections of the first book of Principia in the JE.

These sections represent the foundation and the first steps of Newton's rational mechanics. Hence an analysis of the notes added by the commentators is paradigmatic of their manner to precede and is a necessary introduction to understand the way in which they dealt with the problems deriving from the interpretation and the clarification of every single passage of Newton's text needing of an explanation.

\section{The Four Volumes of Jesuit Edition}

In this section (Tables 1-4), we will provide a general picture of the way in which the footnotes and the addictions exposed in the JE were conceived. Every proposition of the Principia is annotated, therefore here we will focus on the most significant interventions, entering into details, as to the initial six sections of the first book, in the next section.

Table 1.

Volume I containing the first book of the Principia.

\begin{tabular}{|c|c|}
\hline Content & Reference in the JE (Newton 1822) \\
\hline $\begin{array}{l}\text { Long series of notes to the corollary II of Axiomata, sive leges motus, where Newton explains, in his classical } \\
\text { synthetic style, how a correct application of the principle of decompositions of forces can explain the func- } \\
\text { tioning of all machines (even including the muscles and the tendons of the animals) composed of wheels, } \\
\text { pulleys, levers, taut ropes and ascending or descending weights. The notes explain in many details the princi- } \\
\text { ple of decompositions of forces applied to many machines operating under the gravity force and refer results } \\
\text { obtained by Pierre Varignon, Giovanni Alfonso Borelli (1608-1679) and Johann Bernoulli (note 49, p. 22). }\end{array}$ & Ivi, Corollary II, notes 41-49, I, pp. 19-22. \\
\hline $\begin{array}{l}\text { Long series of notes to the corollaries III and IV of Axiomata, sive leges motus, where Newton in the corol- } \\
\text { lary III, explains the principle of conservation of the quantity of motion and shows its basic applications. The } \\
\text { commentators analyse the use of this principle to explain the collision rules between two bodies that mutually } \\
\text { hit with various angles of collision. They analyse the case of the elastic, inelastic and completely inelastic } \\
\text { collisions. Once again they specify and clarify what Newton had exposed in general terms. } \\
\text { The corollary IV is the fundamental proposition according to which the motion of the gravity centre of two or } \\
\text { more bodies does not change its motion for the mutual interactions of the bodies ant it is at rest or moves with } \\
\text { uniform rectilinear motion. Newton provides a correct, but synthetic demonstration expressed in words. The } \\
\text { commentators analyses, in mathematical terms, all the single cases of which Newton spoke and provide more } \\
\text { extended and fully comprehensible demonstrations of Newton's statements. }\end{array}$ & $\begin{array}{l}\text { Ivi, Corollary III and IV, notes 50-73, pp. } \\
23-32 \text {. } \\
\text { Ivi, Notes 50-57, pp. 22-26. }\end{array}$ \\
\hline $\begin{array}{l}\text { Other interesting notes concern the Scholium of the Axiomata, sive leges motus. The commentators show how } \\
\text { infinitesimal physical magnitudes of different order can be geometrically constructed and apply them to } \\
\text { physical reasoning concerning the motion. }\end{array}$ & $\begin{array}{l}\text { Ivi, pp. } 33-44 . \\
\text { Ivi, Notes } 83 \text { and } 84 \text {, pp. } 34-35 \text {. }\end{array}$ \\
\hline $\begin{array}{l}\text { Final notes to the first section (De methodo rationum primarum et ultimarum) of the first book of the Prin- } \\
\text { cipia. The commentators explain in analytical terms the bases of calculus of fluxions and fluents (differential } \\
\text { and integral calculus) that Newton had explained resorting to geometry and passing to the limit in the last } \\
\text { phase of the reasoning. }\end{array}$ & Ivi, Notes 149-170, pp. 61-64. \\
\hline
\end{tabular}

\footnotetext{
${ }^{12}$ As to more modern literature concerning the Principia, we can refer, without pretension to be exhaustive, (generally) to: Panza (2003); Ahnert (2004); Baillon (2004); Bricker \& Hughes (1990); Buchwald \& Feingold (2011); Calinger (1968); Calinger (1969); Carriero (1990); Casini (1998); Cohen (1990); Cohen \& Smith (2002); Crasta (1989); Dear (1998); De Gandt (1995); Ducheyne (2005); Durham \& Purrington (1990); Feingold (2004); Fellmann (1988); Ferrone (1982); Forbes (1978); Force (1983); Force (1985); Force (2004); Force \& Hutton (2004); Guicciardini (1989 et succ.); Hall (1978); Hankins (1990); Haycock (2004); Heimann and McGuire (1971); Hutton (2004a); Hutton (2004b); Jacob (1977); Jacob (1978); KingHele \& Rupert Hall (1988); Mandelbrote (2004); Marcialis (1989); Pulte \& Mandelbrote (2011); Purrington \& Durham (1990); Rattansi (1981); Rouse Ball (1893, 1972), Rupert Hall (1999); Shank (2008); Snobelen (1998); Stewart (2004); Westfall (1971); Westfall (1995); Wigelsworth (2004); Young (2004). We do not refer to unnumbered contributions dedicated to specific problems of Newton's physics and mathematics.
} 


\section{P. BUSSOTTI, R. PISANO}

\section{Continued}

After the first six propositions of the second section of the first book the commentators propose a two pages scholion in which they show the formula obtained by Newton through his geometrical-analytical way of reasoning can be obtained in a mere analytical way. They explicitly rely upon the works of Varignon, Johannes Bernoulli, Hermann and Keill.

One of the most relevant insertion is the note 224. For, it is a brief treatise on the properties of conics sections used by Newton in his Principia. In the Monitum the commentators underline that Calandrini's contribution to this note was decisive because Calandrini edited, ordered the material of the notes and, where necessary, emendated it. Newton often used formulas as "this follows from Conics". For an expert reader, too, the understanding of the property to which Newton is referring is often difficult as well as the finding of Newton's specific source (in general propositions by Apollonius (ca. 262 BC-ca. 190 BC), sometimes De La Hire (1640-1718)). So, this addition is very useful. As to its methodology, the properties of the conics are basically demonstrated through geometrical reasoning, but the explicit resort to trigonometry and to the use of limits is not missing. Therefore this is a precious document of a manner to frame the mathematical reasoning that was typical of the $17^{\text {th }}$ century. Furthermore this treatise is very accurate from the philological point of view, too, because the commentators mention every single Apollonius' proposition they are demonstrating in a manner different from Apollonius'.

Another fundamental series of notes is given by notes 228-245. They concerns the proposition X (a body rotates in an ellipsis. What is the law of the centripetal force that tends to the ellipsis centre). These notes are Ivi, Notes 228-245, pp. 105-114. particularly significant for the explanation of the way how Newton used the concept of osculating circle.

From a historiographic point of view the note 268 is important because the famous inverse problem of the Ivi, Note 268, I, pp. 123-124. forces is dealt with and solved, namely: given the inverse square law and the initial velocity, to prove that the trajectory is a conic section in which the centre of the forces is in one of the foci. It is well known that Newton reported this proposition in I, XIII, Cor 1 and in I, XLI. The historiography has debated whether he had a Ivi, Proposition XLI, Ivi, pp. 245-255. complete demonstration. Nowadays we think he had one.

In Section $\mathrm{V}$ (how the orbits are to be found when neither focus is given), there is a lemma that is fundamental, the lemma XXI: here Newton uses a particular technique to which he also resorted in Enumeratio linearum tertii ordinis. In the notes 310-316 the commentators explain in a very clear manner all the possible figures that can be generated applying the lemma XXI. Once again, in front of a general technique by Newton, they enter into specific examples to make the technique clear to the reader.

Lemma XXII is not less important: Newton explains how to transform a figure into another of the same kind, that is, given an algebraic curve, to transform it into another algebraic curve whose equation has the same degree as the first one. The notes 324-333 clarify Newton's technique that in the text is explained in a very brachilogique way.

Ivi, Note 224, Ivi, pp. 86-103.

Ivi, Monitum, p. VIII

In a Scholium of the fifth section Newton explains how to describe a conic section, given the centre or the asymptotes. His reasoning is completely right, but once again, extremely synthetic. The commentators clarify all the mathematical particulars.

Ivi, Section V, pp. 145-200.

Ivi, Lemma XXI, pp. 155-160.

Ivi, Notes 310-316, pp. 158-161.

Ivi, Lemma XXII, pp. 161-162.

Ivi, Notes 324-333, pp. 169-173.

Ivi, Scholium, pp. 180-190.

Ivi, Notes 339-354, pp. 181-192.

In Section VI (how the motions are to be found in given orbits), the lemma XXVIII ("there is no oval figure Ivi, Section VI, pp. $201-225$.

whose area, cut off by right lines at pleasure, can be universally found by means of equations of any number Ivi, Lemma XXVIII, pp. $203-227$. of finite terms and dimensions" $)^{13}$ presents one of the most genial reasoning by Newton. Newton uses no mathematical symbolism, he uses logic and refined original ideas. The commentators explain step by step Newton's reasoning. In the following section we will analyse in depth this amazing reasoning.

Ivi, Notes 359-362, pp. 203-207.

The notes 365-389 are a complex astronomical and mathematical itinerary to explain the problem posed and the techniques used by Newton in the proposition XXXI and in the following scholion more clearly than Newton did: given an elliptic orbit and the time, to determine the position of the planet. Here the commentators resort to the results and techniques by de l'Hôpital ${ }^{14}$ (1661-1704), Seth Ward (1617-1689), Ismael Boulliau (1605-1694), Giovanni Domenico Cassini (1625-1712), David Gregory (1659-1708), John Keill (16711721).

The proposition XXXIX (VII section) is particularly significant because Newton, given a centripetal force,
and a body that descends or ascend along a straight line, asks to find a plane area proportional to the velocity and a plane area proportional to the time. The problem of the quadrature plays here an important role. The commentators explain in detail Newton's procedure and, basing upon Varignon's results, propose a more analytical approach.

The $8^{\text {th }}$ section is dedicated to the determination of the orbits given by centripetal forces. The orbits are not rectilinear. The fundamental proposition is the XLI, where, given a centripetal force, Newton explains how to determine the trajectory and the time. The problem is difficult. The commentators, according to their usual way of work, explain Newton's methods in detail, propose an analytical approach (Hermann is mentioned) and examine a series of cases not specifically examined by Newton. The result is a sort of treatise on many problems of the central forces (general inverse problem of the forces).

Ivi, Notes 365-389, pp. 209-225.

Ivi, Proposition XXXIX, pp. 236-240.

Ivi, Notes 405-410, pp. 236-240.

Ivi, Section VIII, pp. 241-257.

Ivi, Proposition XLI, pp. 245-255.

Ivi, Notes 417-442, pp. 245-255.

Section X deals with the pendulum-movement and with the motion of the bodies in given surfaces. The fun- Ivi, Section X, pp. 278-310. damental propositions to solve the problem of the isochronism are the LI-LII. As to the motion on a surface, the proposition LVI establishes the trajectory of a body, given the force-law, the surface on which the body Ivi, Proposition LI and LII, pp. 285-289. moves, its axis and the initial velocity. The commentators write a series of continuous and connected notes, in which-as to the problem of the isochronism-specify Newton's way of reasoning and the results obtained by Ivi, Notes 472-491, pp. $295-310$. Huygens (1629-1695), Jakob Bernoulli, Johann Bernoulli and Hermann. With regard to the trajectory problem, they examine in detail a series of example in which the centripetal force is given by different laws and Ivi, These authors are mentioned at p. 300 . different initial conditions to determine the trajectory and viceversa, given a trajectory, they analyse in many cases what force and initial conditions are compatible with that given trajectory. Results of Clairaut (1713-1765) are quoted. Ivi, Clairaut mentioned at p. 307.

\footnotetext{
${ }^{13}$ Translation drawn from Newton, 1729: 1, p. 145

${ }^{14}$ Guillaume François Antoine de Sainte Mesme, marquis de l’Hôpital, or de l’Hospital.
} 


\section{P. BUSSOTTI, R. PISANO}

\section{Continued}

Another very treatise is posed inside the section XIII where Newton deals with the attractive forces of non Ivi, Section XIII, pp. 388-411. spherical bodies. The fundamental propositions are the XCI (to find the attraction of a corpuscle in the axis of a round solid to whose several points there tend equal centripetal forces decreasing in any ratio of the dis- Ivi, Proposition XCI, pp. 395-402. tances whatsoever) $)^{15}$ and the XCII (An attracting body being given, it is required to find the ratio of the decrease of the centripetal forces tending to its several points) $)^{16}$. The scholion is important, too, because Newton Ivi, Proposition XCII, pp. $402-403$. teaches how to abbreviate some calculations resorting to the convergent series. The whole reasoning by Newton is correct both in the propositions and in the scholion, but, as often, it is very synthetic and geometrical. Starting from note 541 until note 557, the commentators transcribe Newton's reasoning in completely analytical terms, provide a series of examples to clarify all situations and analyse in depth the procedures Ivi, Notes 541-557, pp. 395-411. outlined by Newton in the scholion. These pages are a masterpiece of clearness.

Table 2.

Volume II containing the second book of the Principia.

Content

Reference in the JE (Ibidem)

The book is opened by a treatise by Calandrini (asterisk) concerning the general concepts on the motion Ivi, II, pp. 1-11. in resistant means. Results due to Varignon, Johannes Bernoulli, Hermann, Euler (p. 5) are mentioned. A Results mentioned, Ivi, p. 5.

relevant part of the treatise (pp. 5-10) is dedicated to the examination of the logarithmic function that is Examination of logarithmic function, Ivi, pp. fundamental for the study of the motion in resistant means. Page 12 is a series of brief considerations on 5-10. the maxima and minima.

Considerations on maxima and minima, Ivi, p. 12

In the proposition IV of Section I and in the seven subsequent corollaries, Newton examines the motion Ivi, Proposition IV, pp. 21-31.

of a projectile subjected to the gravity, under the hypothesis that the resistance of the air is proportional to the velocity. The commentators explain all the passages trough which Newton constructs the figure in the text and develops his reasoning. But the most important contribution concerns the notes to Newton's Ivi, Notes 54-67, pp. 23-31. scholion. Here the commentators: a) clarify how, given the equation of a curve, it is possible to construct the curve exploiting the logarithmic function (notes 68-71) (here the technique of Varignon and Hermann is referred and also a letter by Newton to Oldenburg (1618-1677) in 1676, see, note 68); b) deal with the Ivi, Notes 67-77, pp. 31-36. problem of the angulum elevationis, that is how vary the trajectory of a projectile in function of the angle with which the projectile is shot and of its initial velocity (notes 72-74); c) show how to describe a regular curve passing through a series of given points. This problem is difficult and, in general, if the kind of curve is not specified, it can be solved by approximation with convergent series. The commentators remind the reader (note 75) that Newton dealt with this problem in his Arithmetica Universalis, providing the method, but not the demonstrations. The long following notes $(76,77)$ concern the treatment of this question, also exploiting some results due to Hermann, Craig (died 1620) and Stirling (1692-1770).

In the II section, a fundamental proposition is the IX one with its seven corollaries: Newton, given a Ivi, Proposition IX, pp. 52-62. speed (or better, of trigonometric functions proportional to the speed). The commentators do not limit to Ivi, The two problems, pp. $60-63$. explain in every detail the assertions given by Newton in the corollaries, but also add two problems to complete Newton's results, also exploiting Euler's researches.

Ivi, Euler's researches, p. 63.

In conclusion at Section II, the commentators pose a general problem plus a series of connected corollaries: given the gravity, acting perpendicularly to the horizon, in a uniform manner, to determine the trajectory described by a projectile in a uniform resistant means, being the resistance proportional to an Ivi, Notes 127-137, pp. 88-93. arbitrary power of the speed.

In Section IV, Newton deals with the circular motion in resistant means. In this context the fundamental curve is the logarithmic spiral. Calandrini poses two pages where he describes all properties of this curve Ivi, Notes 147-156, pp. 110-111. necessary to understand Newton's reasoning.

Section IV is closed by another problem posed and solved by the commentators: let the centripetal force tend to a centre $\mathrm{C}$ and in a point $\mathrm{P}$ let it be inversely proportional to a power of the distance CP. Let the resistance of the means be as the means-density and as a certain power of the velocity. The density of the means in every single point of the trajectory, its resistance and the speed of the body are required so that the body moves on a given curve.

Section VI concerns the motion and the resistance of the oscillating bodies. The whole section is densely Ivi, Proposition XXIX, pp. 157-163. annotated. The most relevant interventions are maybe the following ones: a) in the proposition XXIX and its three corollaries, Newton, given a body oscillating along a cycloid with a resistance proportional to the square of its velocity, finds the resistance in every point of the trajectory. Newton himself claims the complete calculations are very difficult and because of this, he adds another proposition to simplify them. Ivi, p. 163. Calandrini does not get discouraged and develops the whole calculation (he mentions Hermann); b) the Ivi, General Scholium, pp. $170-190$. section VI ends with a fundamental scholion where Newton shows a series of experiments carried out by him as to the oscillating movements in resistant means and connects these experiments with theory. Newton reminds the reader that, according to his previous results and given some initial conditions, the Ivi, pp. 172-174. Really in these three pages there highest velocity during an oscillation is major in a cycloid than in a circle according a certain proportion, are only 13 lines of text. All the rest is composed while the times are longer in the circle than in the cycloid according to the inverse proportion of the of notes. speeds. Calandrini examines these properties in all mathematical details so that the reader is guided to a full understanding of the problem; c) two problems are added to Newton's scholion and solved: 1) to find the resistance of a tended oscillating thread in a resistance means in which the resistance itself is proportional to the squares of velocity and of the diameter; 2) given the gravity, to determine the motion of a Ivi, Note $i$, pp. 173-175. For the two problems, body ascending and descending in a curve under the condition that the resistance is proportional to an see note 184 , Ivi, p. 179 and note 188 , pp. 188arbitrary function of the velocity. 190 .

${ }^{15}$ Translation drawn from Newton, 1729: I, p. 302.

${ }^{16}$ Translation drawn from Newton, 1729: I, p. 305. 


\section{P. BUSSOTTI, R. PISANO}

\section{Continued}

Section VII concerns the motions in the fluids and the resistance of the projectiles. Newton deals with various problems connected to the resistance found by solids of different forms moving in fluids. The Ivi, Notes 202-209, pp. 203-207. important problem to find the solid of rotation that, given some initial conditions, opposes the least resistance to the movement in a resistant means is dealt with. The works by Johann Bernoulli (who solved the Ivi, p. 207. problem in general) and by Hermann are mentioned.

In the VIII section, Newton provides the fundamental propositions concerning the vibrating cords and the propagation of the motion in the fluids. The commentators add a series of further propositions on the vibrating cords, also connected with music and refer experiments and results, for example by 's Gravesande and Marin Mersenne (1588-1648).

The note 315 begins as a series of annotations to proposition XLVII where Newton shows the relations Ivi, Note 315, pp. 271-287. between the motion of the particles of a fluid to which a series of impulses have been given and the motion of a pendulum, but becomes a very treatise on the motion in a fluid. Every result is obtained following Newton's methods. Euler and Gabriel Cramer (1704-1752) are mentioned. The note is written by Calandrini.

Ivi, Notes 300-311, pp. 262-265.

Ivi, p. 263.

Ivi, p. 273.

Table 3.

Volume III containing the initial 24 propositions of the third book of the Principia.

\section{Content}

The commentators premise to Newton's work an introduction, that is a brief treatise on positional astronomy Ivi, III, pp. IX-XXXVI. divided into three chapters: I) Quale oculo nudo appareat mundi systema paucis exponitur, et prima Astronomiae Elementa breviter revocatur (brief exposition how the system of the world appears to naked eye and Ivi, pp. IX-XX. brief note on the initial elements of astronomy); II) Siderum refractio and parallaxis breviter explicatur (brief explanation of the stars-refraction and parallax); III) De Telescopii ac Micrometri usu et Phaenomenis Ivi, pp. XXI-XXVIII. horum Instrumentorum beneficio observatis pauca (Few considerations on the use of the telescope and of the micrometer and on the phenomena observed thanks to these instruments).

In the section of the third book called Phaenomena, the first phenomenon described by Newton concerns the fact the Jupiter satellites respect the third Kepler law. Calandrini puts a long series of notes concerning the Ivi, Notes 51-56, pp. 5-10. determination of the motion of Jupiter and Saturn satellites, the use of the telescope in these specific cases and the problem of the periodical times of the satellites (Cassini is mentioned as well as Huygens, Horrocks (1618-1641), Hevelius (1611-1687), Galletius and Halley (1656-1742)). With regard to the other five celestial phenomena described by Newton, the notes are as profound as those concerning the first phenomenon.

In the fifth corollary to proposition VI Newton briefly explains the qualitative differences between the grav- Ivi, p. 29. ity and the magnetism. Calandrini in a five pages note (pp. 29-33) refers a series of experiments and conclusions by Muschenbroek (1692-1761) and Winston (1667-1752) on the terrestrial magnetism. On the basis of Ivi, pp. 29-33. these experiments and calculations Calandrini formulated the conjecture that the magnetic force decreases almost as the cube of the distance. He wrote: "From the previous [experiments and calculations], I think it is proved with a sufficient certainty that the magnetic force decreases almost as the cube of the distance from the magnet, at least according from what can be ascertained from those rather rude observations"17. Ivi, p. 32, final four lines.

Two interesting notes are the 72 and 73: Newton in the corollary two of proposition XIV claimed that the parallax due to the annual motion of the earth is insensitive. Calandrini in the mentioned notes dealt with the parallax-problem and exposed an attempt ideated by Huygens to calculate the distance-relation between the Sun and the fixed stars based on supposed parallaxes.

In the proposition XVII Newton proves that the diurnal movements of the planets are regular and that Moon Ivi, Proposition XVII, pp. 51-54. libration is due to its diurnal movement. He claims that the libration theory exposed by N. Mercator (1620-1687) and published in 1676 is completely drawn from his own letters. The commentators refer a brief summary of the theory, written by Mercator himself, in which he clearly explains that his results are due to Newton's letters.

Ivi, Note 78, pp. 53-54.

The propositions XIX and XX concern, in substance the way in which the gravity changes in different points Ivi, Proposition XIX, pp. 55-77. of the Earth and are hence strictly connected to the problem of the Earth form. A real treatise, presented as a Ivi, Proposition XX, pp. 78-87. series of notes to these two propositions and divided into different sections, on the problem of gravitational attraction, is presented by the commentators and by Calandrini in which the whole knowledge (year 1742) Ivi, pp. 55-87. on this subject is exposed. These series of notes are dense. After a description of observations and experiments due to authors mentioned by Newton himself (as Picard (1620-1682) and Cassini) and others not mentioned (as George Graham (1673-1751), de Mairan (1678-1771) and Maupertius (1698-1759)) a series Ivi, pp. 55-59. of theoretical propositions follows in which the gravity of bodies of different form is analysed, considering the cases in which the density is uniform and the cases in which it varies in a given manner. An important problem is dealt with: given the equation of a curve, that rotating around an axis originates a solid of rotation, to find the attractive force acting on a corpuscle posed in an arbitrary point of the solid-surface.

In the proposition XXIV Newton proves that the tides depend on Sun and Moon action. The commentators, Ivi, Proposition XXIV, pp. 92-98. after this proposition add the following treatises on the tides and on the form of the Earth inside the third volume: A) Daniel Bernoulli: Sur le Flux et Reflux de la Mer, 1740; B) Colin McLaurin (1698-1759): De Ivi, pp. $101-207$. causa physica fluxus et refluxus maris, 1740; Leonhard Euler: Inquisitio physica in causam fluxus ac re- Ivi, pp. 209-245. fluxus maris, 1740. These works had won the praise of the Académie royale des Sciences. Ivi, pp. $247-341$.

\footnotetext{
${ }^{17}$ Original Latin text: "In recessu a magnete vim magneticam decrescere in ratione fere triplicate quantum saltem crassis illis observationibus animadverti potest”. Our translation from Latin into English.
} 
Volume IV containing propositions XXV-XLII of the third book of the Principia and the General scholium.

\begin{tabular}{|c|c|}
\hline Content & Reference in the JE (Ibidem) \\
\hline The volume opens with an introduction to Newton's lunar theory written by the commentators. & $I v i$, IV, pp. III-VI \\
\hline $\begin{array}{l}\text { Newton, in the proposition XXVI, poses and solves the problem to find the hour-increment of the area described by the } \\
\text { moon in its revolution around the earth. The geometrical proofs given by Newton need a series of complicated calculations } \\
\text { described in their general lines by Newton. Calandrini explains all calculations in details and adds a further problem: given } \\
\text { the hypotheses of the proposition XXXVI, to expose the reasoning according to which the momenta of the considered area } \\
\text { are described. }\end{array}$ & Ivi, Proposition XXVI, pp. 4-10. \\
\hline $\begin{array}{l}\text { In the proposition XXIX, Newton shows how to find the lunar inequality called variation. Calandrini adds a long series of } \\
\text { notes, that are far longer than Newton's explanation, and puts in evidence every single step of the whole problem develop- } \\
\text { ing every reasoning and calculation in a clear manner. }\end{array}$ & Ivi, pp. 17-21. \\
\hline $\begin{array}{l}\text { In the proposition XXX Newton tackles the difficult problem to find the motion of the moon nodes in a circular path. Once } \\
\text { again the notes of Calandrini constitute a very treatise that provides the reader all details on this difficult problem. The } \\
\text { same considerations can be developed as to the other three problems dealt with by Newton with regard to the motion of } \\
\text { moon nodes; prop. XXXI: to find the motion of the moon nodes in an elliptic path; prop. XXXII: to find the average mo- } \\
\text { tion of the moon nodes; prop. XXXIII: to find the real motion of the moon nodes. Actually, all notes concerning Newton's } \\
\text { theory of the motion of moon nodes represent a precious series of knowledge, useful both to understand the phenomenon, } \\
\text { to realize how Newton reasoned and to understand the physical-mathematical set of problems behind this refined ques- } \\
\text { tion. }\end{array}$ & Ivi, pp. 22-51. \\
\hline $\begin{array}{l}\text { Maybe the most surprising insertion of the commentators is a } 30 \text { pages treatise whose first part is titled: De incremento } \\
\text { motus medii Lunae, et eius aequatione annua, ex Solis actione pendentibus, primum hypothesi orbem Lunae esse circula- } \\
\text { rem, postea in hypothesi orbem Lunae esse ellipticum. Denique in orbe lunari ad eclipticam inclinato. (On the increment } \\
\text { of the average motion of the moon, and that of its annual equation, depending on sun action, at the beginning in the hy- } \\
\text { pothesis that Lunar path is circular, then elliptic. Finally in the hypothesis that lunar path is inclined on the ecliptic). Here } \\
\text { the concepts and the results known at that time as to the lunar theory are reported. The reader can get a complete under- } \\
\text { standing of Newton's methods and its transcription into more analytical terms. }\end{array}$ & Ivi, pp. 64-95. \\
\hline $\begin{array}{l}\text { The further long series of notes concern Newton's theory on the comets. Here the notes between pages } 147 \text { and } 157 \text { repre- } \\
\text { sent a brief treatise whose first part is on this subject, where Newton's theory is clarified in many details. }\end{array}$ & Ivi, pp. 147-157. \\
\hline
\end{tabular}

In the following based on the previous tables we provide the analyses of the main parts of Newton's content and JE's notes.

\section{Analysis of the Notes in the First Six Sections of the First Book}

The first six sections of the first book provide the initial foundations of Newton's rational mechanics. They are hence particularly important because of the basic character of the results dealt with. Therefore the way in which the commentators annotated these sections highlights their general style and is paradigmatic of their work. Schematizing, we can distinguish three kinds of notes:

1) Notes strictly connected to the text, that is notes whose scope is a direct clarification of Newton's reasoning;

2) Notes in which notions that are not present in Newton's book, but that are necessary for its comprehension, are introduced;

3) Notes in which the solutions of Newton's problems provided by authors who operated after the publication of Principia are presented.

We supply three examples we believe significant for the understanding of the kind of contributions provided by the commentators.

\section{Example 1. Book I, Section II, Proposition VI: The Relation between Centripetal Forces, Versed Sine and Time}

Let us begin with a proposition whose demonstration is not difficult and that is a good introduction to the work of the commentators. Here we have an example of the notes of kind 1) and 3) above cited. The proposition is the VI of the second section (Newton, 1822: I, p. 79, see Figure 2):

Newton supplies a five-line demonstration in words. Of course this is enough if the scope is to provide correct proofs. But, if the scope is to put the reader in the best possible condition to understand every detail of the text, then the note (Newton, 1822: I, note 207, p. 79) of the commentators is useful ${ }^{13}$ : They explain the reasoning in detail in this manner: let us suppose that two bodies $P$ and $p$ rotate around the curves $A P Q$ (Figure 3) and $a p q$ (Figure 4, the points $a$ and $q$ are not indicated and $P$ has to be replaced with $p$. This is a print mistake of the edition).

Let $\mathrm{DH}$ and $d h$ be the chords described in the minimum (infinitesimal) time. This means that Newton is looking for instantaneous quantities. Let the radio vectors $S P$ and $s p$ divide these chords in two equal parts. The segments $P C$ and $p c$ are hence the versed sins. But (Principia, Lemma VII, Cor. 2), given evanescent quantities, the chords and the arcs tend to a reason of equality, hence $D C=C H=\operatorname{arcDP}=\operatorname{arcPH}$. When the points $C$ and $P, c$ and $p$, converge, the points $D$ and $H, d$ and $h$, tend to respectively coincide with the points $P$ and $p$. Therefore the last position of the evanescent chords $D H, d h$ is the same as the position of the tangents $F L$, $f l$, so that the lines $D H, F L$ and $d h, f l$ tend to become parallel. Thus, the last reason of $D F$ and $C P$ is a reason of equality as well as that of $d f$ and $c p$. Given these premises the proof runs as follows: let us suppose that the arcs $P D$ and $p d$ are described in the same time. In the Prop. I, Corollary $4^{22}$ (Newton, 1822: I, p. 67), Newton proved that, under this condition, the forces in $P$ and $p$ are as the versed sins $C P$ and $c p$. On the other hand, let us suppose that the forces in $P$ and $p$ are equal, but that the time in which the in-

\footnotetext{
${ }^{18}$ To facilitate the comprehension of the reasoning, we report the two imagines in a bigger format than in Figure 2.
} 


\section{P. BUSSOTTI, R. PISANO}

\section{Liber Primus.] Principia mathematica.}

PROPOSITIO VI. THEOREMA V

Si corpus in spatio non resistente circa centrum immobile in orbe quocunque revolvatur, et arcum quemvis jamjam nascentem tempore quam minimo describat, et sagitta arcus duci intelligatur, que chordam biseset, et producta transeat per centrum virium: erit vis centripeta in medio arcus, ut sagitla directè et tempus bis inversè.

(i) Nam sagitta dato tempore est ut vis (per Corol. 4. Prop. I.) et augendo tempus in ratione quâvis, ob auctum arcum in eádem ratione sagitta augetur in ratione illâ duplicatâ (per Corol. 2, et 3. Lem. XI.) ideoque est ut vis semel et tempus bis. Subducatur duplicata ratio temporis utrinque, et fiet vis ut sagitta directè et tempus bis inversè. Q. e. d.

(') 207. Corpora $P$ et $p$, circè virium cen-
tra $S$ et s, revolvendo, curvas $A$ P $Q$, a p q, de-
scribant, sintque chorde minimse $D$ H, dh, rascribant, sintque chordxe minims $\mathrm{D} \mathrm{H}, \mathrm{d} \mathrm{h}$, ria-
diis vectoribus $\mathrm{S} \mathrm{P}, \mathrm{sp}$, bifariam divisis, et chordiis vectoribus $\mathrm{S} P, \mathrm{sp}$, bifariam divisis, et chor-
dis illis evanescentibus, erit $\mathrm{CH}=\mathrm{P}$, et D C =DP (per Corol. 2. Lem. VII.) adeóque
P H $=P$ P ; undè puncta $P$ et p, sunt in me dio arcuum evanescentium $\mathrm{DPH}, \mathrm{d} \mathrm{ph}$, posit. Praterea quoniam punctis $\mathrm{C}$ et $\mathrm{P}$, c et $\mathrm{p}$, coeunti$\mathrm{P}$, p, coincidunt, ultima chordarum evanescentium $\mathrm{DH}, \mathrm{dh}$, positio congruit cum tangentum $\mathrm{F} \mathrm{L}$, $\mathrm{fl}$ positione, ac proindè chordx eval escentes $\mathrm{D} \mathrm{H}, \mathrm{dh}$, tangentibus $\mathrm{F} \mathrm{L}$, $\mathrm{fl}$, rqui-
distant, adéórue rectec $\mathrm{D} F, \mathrm{~d} f$, radiis $\mathrm{S} \mathrm{P}, \mathrm{sp}$, paralleles sagittis P C, p c, evanescentibus xquales sint. His, ad clariorem eorum que Nrwro Nus supponit, intelligentiam positis, demonstran-
dum est vires centripetas in $P$ et $p$, esse inter dum est vires centripetas in $\mathrm{PagittaP} \mathrm{C}, \mathrm{p} \mathrm{c}$, directè, et inversè ut quadrata temporium quibus describuntur arcus evanescentes $\mathrm{HPD}, \mathrm{h}$, , aut dimidii $\mathrm{PD}, \mathrm{P}$ -Dem. Si arcus $\mathrm{P} \mathrm{D,} \mathrm{p} \mathrm{d,} \mathrm{equalibus} \mathrm{ten-}$ Corol. 1. Prop. I.) essent ut vires centripete in $P$ et $p$. Quòd si vires in $P$ et $p$, xquales forent, tempora verò per arcus $\mathrm{P} D, \mathrm{p}$, inzqualia, $\mathrm{PC}, \mathrm{p}$ fore ut horum temporum quactrata directe; s sive eodem tempore t quo arcus $\mathrm{pd}$, positis viribus in $P$ et $p$, xqualibus, spatia $Q \mathrm{Q}, \mathrm{fd}$, seu $\mathrm{P}$

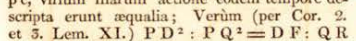
et 3 . Lem. XI.) $\mathrm{PD}^{2}: \mathrm{PQ}^{2}=\mathrm{DF}: Q$
sive $\mathrm{fd}$, et obmotum per arcuseranescentes un formem, sunt arcus $\mathrm{PD}, \mathrm{PQ}$ ut tempora $q$

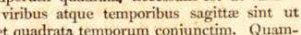
P D 2.reribuntur, hoc est ut $\mathrm{T}$ ad th, ideoque obrem si vires in $\mathrm{P}$ et $\mathrm{P}$, dicantur $\mathrm{V}$, $\mathrm{v}$, erit d, et qiaia $D F=P C$ et $d f=p c$ ergo $T^{2}:$ tecedentes per $T^{2}$, et consequentes per $t^{2}$, erit $\mathrm{t}^{2}=\mathrm{PC}: \mathrm{pc}$, itaque si vires in $\mathrm{P}$ et $\mathrm{p}$ sin mquales, erunt sagitte $\mathrm{PC}, \mathrm{pc}$, ut quadrat

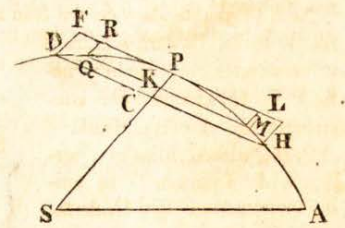

Proposition VI. Theorem V

In a space void of resistance, if a body revolves in any orbit about an immoveable centre, and in the least time describes any arc just then nascent; and the versed sine of that arc is supposed to be drawn, bisecting the chord, and produced passing through the centre of force: the centripetal force in the middle of the arc, will be as the versed sine directly and the square of time inversely.

Figure 2.

Proposition VI. Theorem $\mathrm{V}^{19}$.

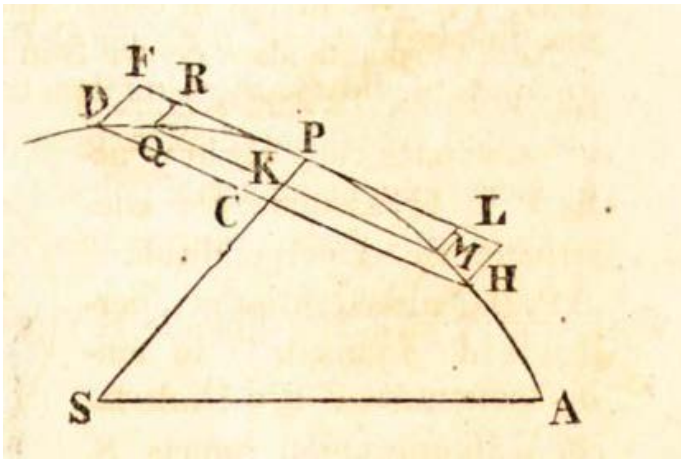

Figure 3.

Particular of Figure $2^{20}$.

${ }^{19}$ Newton, 1822: I, p. 79. English translation from Newton, 1729: p. 68.

${ }^{20}$ Newton, 1822: I, p. 79.

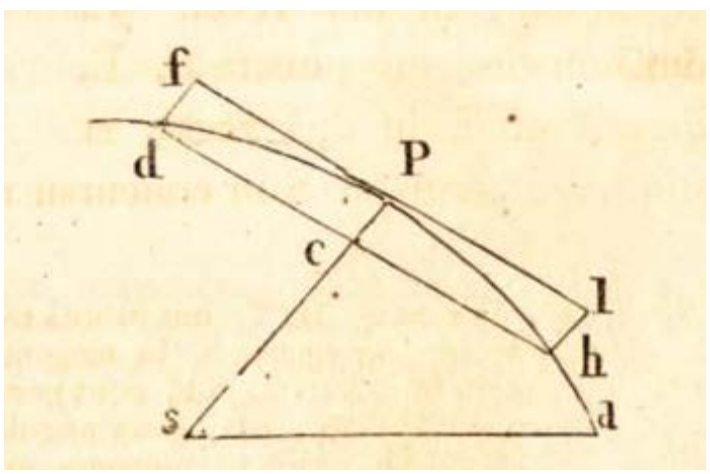

Figure 4.

Particular of Figure $2^{21}$

finitesimal arcs are described is different and let the arc $P Q$ be described in the same time as the arc $p d$. Furthermore since the forces in $P$ and $p$ are supposed to be equal, the spaces $Q R, f d$, $P K$ and $p c$ are described in the same time because the action of the forces (these spaces indicate in fact the deviation from a rectilinear trajectory) are equal. For Lemma XI, Cor. 2 and 3 (Newton, 1822: I, pp. 54-55) the following relation holds:

$$
P D^{2}: P Q^{2}=D F: Q R,
$$

with $Q R=f d$. Furthermore, if an arc is evanescent, the motion describing it, can be considered uniform, therefore the evanescent arcs are as the times and if $T$ indicates the time in which the arc $P D$ is described we have, also considering (1):

$$
P D^{2}: P Q^{2}=T^{2}: t^{2}=D F: Q R(=f d) .
$$

Since $D F=P C$ and $d f=p c$, one has:

$$
T^{2}: t^{2}=P C: p c
$$

That is: the versed sins are as the squares of the times. But, for a given time, the versed sins are as the forces. Therefore, if both times and forces vary, the versed sins are as the product of the forces and of the squares of time. Hence if $V$ and $v$ indicate the forces we have:

$$
P C: p c=V \cdot T^{2}: v \cdot t^{2}
$$

And finally

$$
V: v=\frac{P C}{T^{2}}: \frac{p c}{t^{2}} .
$$

In its ease, this is a good example of the kind A) of notes and of the way in which Newton used the method of the first and last reasons.

The five corollaries to this proposition provide a good example of notes of kind C). The corollaries are the following (See Figure 5):

The point $S$ = centre of the force; curved line $A P Q=$ trajectory; $Z P R=$ tangent in $P ; Q R$ parallel to $S P ; Q T$ perpendicular to $S P$; $S Y$ perpendicular to $Z P R$, then:

Cor 1: when $Q$ tends to $P$ (namely $Q P$ becomes infinitesimals), the centripetal force is inversely proportional to the solid (today we say simply to the quantity) $\frac{S P^{2} \cdot Q T^{2}}{Q R}$;

\footnotetext{
${ }^{21}$ Newton, 1822: I, p. 79.

${ }^{22}$ The commentators write corollary 1 , but this is clearly a mistake, the corollary to consider is the number 4 .
} 


\section{PHilosophiÆ Naturalis Mot. Corror.}

(g) Idem facilè demonstratur etiam per Corol. 4 Lem. X.

Corol. 1. Si corpus P revolvendo circa centrum $\mathrm{S}$ describat lineam curvam A PQ; tangat verò recta $\mathrm{Z} P \mathrm{R}$ curvam illam in puncto quovis $\mathrm{P}$, et ad tangentem ab alio quovis curvæ puncto $Q$ agatur $\mathrm{Q} R$ distantiæ $\mathrm{S} P$ parallela, ac demittatur $Q T$ perpendicularis ad distantiam

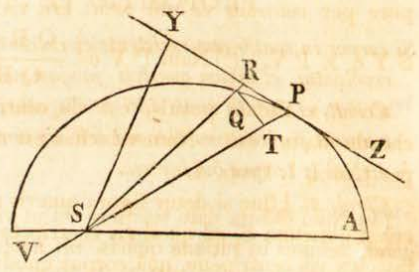

illam S P: vis centripeta erit reciprocè ut solidum $\frac{S \text { P quad. } \times Q T \text { quad. }}{Q R}$; si modo solidi illius ea semper sumatur quantitas, quæ ultimo fit, ubi cö̈unt puncta $P$ et $Q$. ( $\left.{ }^{\text {h }}\right)$ Nam $Q R$ rqualis est sagittæ dupli arcus $Q P$, in cujus medio est $\mathrm{P}$, et duplum trianguli $\mathrm{S} Q \mathrm{P}$ sive $\mathrm{S} \mathrm{P} \times \mathrm{Q}$, tempori, quo arcus iste duplus describitur, proportionale est; ideoque pro temporis exponente scribi potest.

Corol. 2. Eodem argumento vis centripeta est reciprocè ut solidum $\frac{\mathrm{S} Y \mathrm{q} \times \mathrm{QP} \mathrm{P}}{\mathrm{QR}}$, si modò $\mathrm{S} \mathrm{Y}$ perpendiculum sit à centro virium in orbis tangentem $P R$ demissum. (i) Nam rectangula $S \mathrm{Y} \times \mathrm{Q} P$ et $\mathrm{S} P$ $\times Q \mathrm{~T}$ æquantur.

Corol. 3. Si orbis vel circulus est, vel circulum concentricè tangit, aut concentricè secat, id est angulum contactus aut sectionis cum circulo quam. minimum continet; eandem habens curvaturam eundemque ra-

( $\left.{ }^{8}\right)$ 208. Idem facilè demonstratur etiam basim $\mathrm{SP}$; cum igitur in eâdem curvà A P Q per Corol. 4. Lem. X. quo statuitur vires esse ut arex sint proportionales temporibus quibus despatia, ipso motus initio, descripta directe et qua- scribuntur, ac proinde rectangulum Q T $\times S \mathrm{P}$,

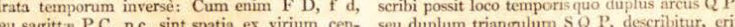
Q R . cri quibus percurruntur arcus evanescentes $\mathrm{P} D$, vis centripeta in $\mathrm{P}$, directè ut $\frac{\mathrm{SP}^{2} \times \mathrm{QT}^{2}}{\mathrm{St}}$ petas esse inter se in ratione compositâ ex directh ratione sagittarum $\mathrm{PC}$, p c, et reciproci qua210. Rectangula

Rectangula $S$ Y $X$ Q P, et S P X

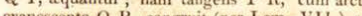
(b) 009 Non $Q$ R allo pli arcus $Q \mathrm{P}$, in cujus medio est $\mathrm{P}$, (207), du- trianguli $\mathrm{S} \mathrm{P}$ Q, basis $\mathrm{P}$ Q, producta, et $\mathrm{S}$ Y, plum verò trianguli evanescentis $S Q P$, (quod tanquam perpendicularis ad illam basim produc-
per Lem. VIII., tanquamrectilineum considerari tam, quarè area dupli wrianguli S P Q est S Y potest) squale est facto ex perpendiculo $Q \mathrm{~T}$, in $\times Q \mathrm{P}=\mathrm{SP} \times \mathrm{P}$.

,

Figure 5.

Corollaries 1, 2, 3 to the proposition $\mathrm{VI}^{23}$.

Cor 2: the centripetal force is inversely proportional to $\frac{S Y^{2} \cdot Q P^{2}}{Q R}$

Cor 3: let $P V$ be a chord of the circle osculating the trajectory in $P$, then the centripetal force is inversely proportional to $S Y^{2} \cdot P V$;

Cor 4: under the same conditions, the centripetal force is directly proportional to the speed-square and inversely proportional to the chord $P V$;

Cor 5: it is a summary of the previous corollaries.

The proof of these corollaries is not difficult and the commentators add only some brief notes. But they write five notes (Newton, 1822: I, 212-216, pp. 81-82; the notes 213-216 are included in a Scholium) in which the methods used by other authors to determine the centripetal force are referred:

In the note 212 (Figure 6), being FVP the circle (whose centre is $C$ and radius $C P=R$ ) osculating the trajectory in $P$, Johann Bernoulli, Abraham de Moivre (1667-1754) and Guido Grandi (1671-1742) proved that the centripetal force is in-

\footnotetext{
${ }^{23}$ Newton, 1822: I, p. 80.
}

versely proportional to

$$
\frac{S Y^{3} \cdot R}{S P}
$$

This depends on the fact that

$$
S Y^{2} \cdot P V=\frac{S Y^{3} \cdot R}{S P}
$$

The not difficult proof is referred.

Liber Prinus.] Principia mathematica.

dium curvaturæ ad punctum $\mathrm{P}$; et si $\mathrm{P} \mathrm{V}$ chorda sit circuli hujus à corpore per centrum virium acta: erit vis centripeta reciprocè ut solidum $S Y q \times P V .\left({ }^{k}\right)$ Nam $P V$ est $\frac{Q R q .}{Q R}$

Corol. 4. Iisdem positis, est vis centripeta ut velocitas bis directè, et chorda illa inversè. Nam velocitas est reciprocè ut perpendiculum S Y per Corol. 1. Prop. I.

Corol. 5. Hinc si detur figura quævis curvilinea A P Q, et in ea detur etiam punctum $\mathrm{S}$, ad quod vis centripeta perpetuo dirigitur, inveniri potest lex vis centripetæ, quâ corpus quodvis $\mathrm{P}$ à cursu rectilineo perpetuo retractum in figuræ illius perimetro detinebitur, eamque revolvendo describet. Nimirum computandum est vel solidum $\frac{S \mathrm{P} q \times \mathrm{QT} q}{Q R}$ vel solidum $\mathrm{S}$ Y q $\times$ P V huic vi reciprocè proportionale. Ejus rei dabimus exempla in problematis sequentibus.

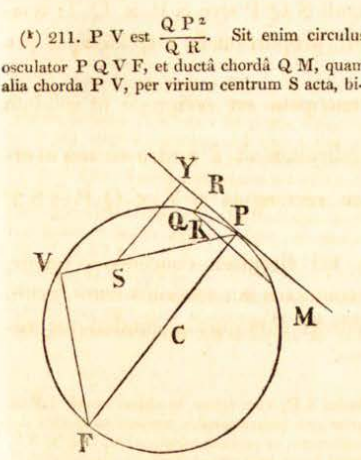

F C P, ad tangentem $\mathrm{P}$ Y, perpendiculares wquidistant, erit angulus V P F $=P$ S Y c cum que sit pratereà angulus $\mathrm{F}$ V P, in semicirculo xqualis recto $S$ Y $P$, duo triangula $P$ V $F$,
S Y P, similia sunt ac proindè S P : S Y

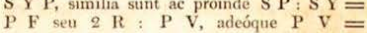
$\frac{\mathrm{SY} \times 2 \mathrm{R}}{\mathrm{SP}}$ et $\mathrm{SY}^{2} \times \mathrm{PV}=\frac{\mathrm{SY}^{3} \times 2 \mathrm{R}}{\mathrm{SP}}$; hoc est dividendo per numerum constantem 2, ut $\frac{\mathrm{S} \mathrm{Y}^{3} \times \mathrm{R}}{\mathrm{SP}}$. Hac est expressio vis centripetæ quam Joannes Bernoullius, Abrahamus de Noivre et Guido Grandus invenerunt.

$$
\text { SCHOLION: }
$$

213. NEwrosus generalem virium centralium theoriam in superioribus propositionibus aperuit, Corollariis tradidit. Plurimas per analysim me thodumque fluxionum posteà exquisierunt alii secat in K, erit (per Prop. s5. Lib. 5. Elem.) qui primum inter Geometras locum tenebant. $\mathrm{RK}^{2}=\mathrm{VK} \times \mathrm{PK}$; sed evanescente P K, tariis Parisiensibus an. 1700, 1701, 1706, viri-
$\mathrm{VK}=\mathrm{VP}$, et $(207) \mathrm{QR}=\mathrm{PK}$, ac per

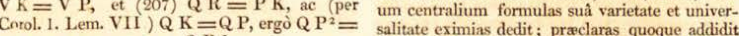

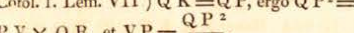
$\mathrm{R}$, et $\mathrm{VP}=\frac{\mathrm{QP}}{\mathrm{QR}}$

212. Iisdem positis sit $\mathrm{PC}$, radius osculi= $\mathrm{R}$, et erit vis centripeta in $\mathrm{P}$, reciprocè ut solidurn $\frac{\mathrm{SY}^{3} \times \mathrm{R}}{\mathrm{SP}}$ : quoniam enim recte $\mathrm{SY}$, et

Vor. I. Joannes Bernoullius in iisdem Commenturiis id 1710. Duas proposuit Jacobus Hermannus in cholio ad Propositionem 22am Lib. 1. Phoronomice, quas ut pote multum expeditas, nobisque in posterum profuturas, et ex superioribus $\mathrm{N}_{\mathrm{E} W-}$ rosı formulis facillime ded

Figure 6.

Final reasoning of the note $212^{24}$.

Newton's proposition VI with its corollaries and the note 212, too, provides a form of the centripetal force that is really a differential form because the time and the distance $P Q$ tend to 0 , but this form is presented as a relation between segments (that are in fact traced on a figure). In the Scholium (Newton, 1822: I, notes 213-216) the commentators arrive at a form of the centripetal force that is explicitly a differential form, from the notational point of view, too. Things work like this (Newton, 1822: I, note 214, see Figure 7): 


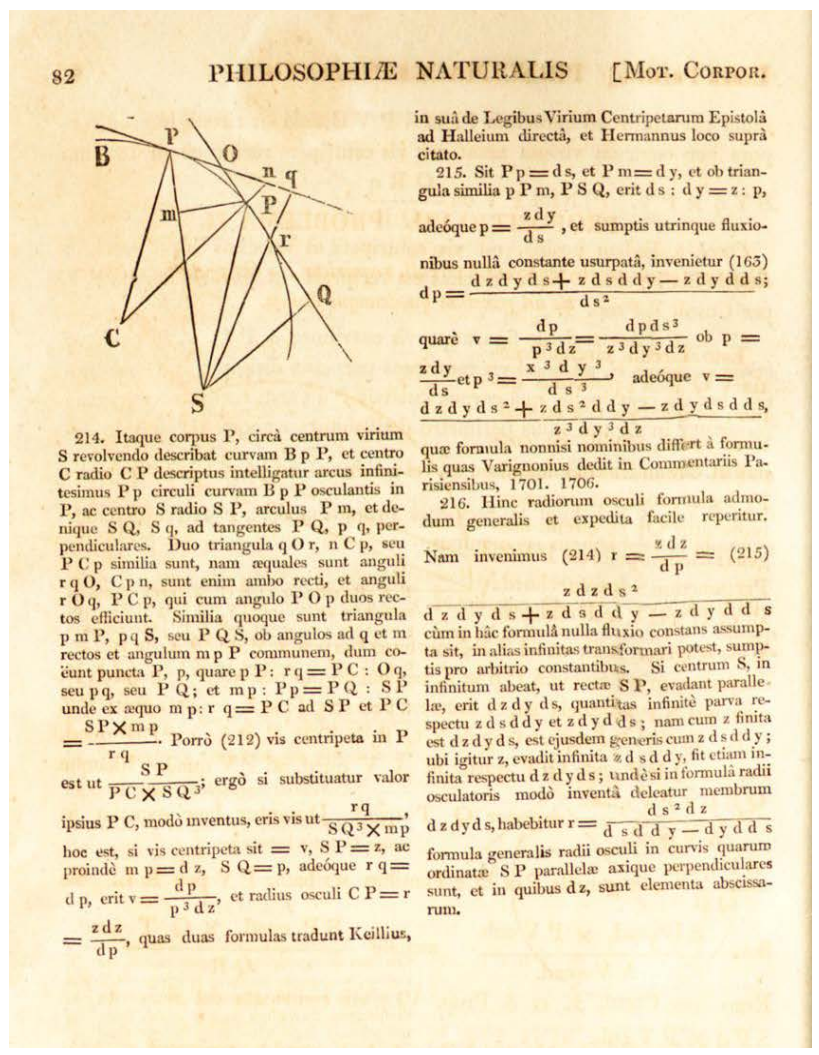

Figure 7.

The Scholium of the commentators to proposition $\mathrm{VI}^{25}$.

$B p P=$ trajectory; $C=$ centre and $C P=$ radius of osculating circle in $P ; p P=$ infinitesimal arch; $S$ = centre of the force; $S Q$ and $S q$ perpendiculars in $Q$ and $q$ to the tangents $P O$ and $p O$ respectively. The point $r$ belongs to the tangent; $m P$ is perpendicular to $S p$. Through a geometrical reasoning referred by the commentators it is possible to prove that

$$
\frac{S P}{P C \cdot S Q^{3}}=\frac{r q}{m p \cdot S Q^{3}}
$$

This means that the centripetal force is as

$$
\frac{r q}{m p \cdot S Q^{3}}
$$

Let us now indicate the force by $v$ and $S P$ by $z$. If $p$ and $P$ converge, then $m p=d z$, and posed $S Q=p$, it is $r q=d p$, therefore

$$
v=\frac{d p}{p^{3} d z} \text { and } C P=r=\frac{z \cdot d z}{d p}
$$

The commentators underline that these formulas are due to the Epistola de legibus virium centripetarum by Keill to Halley and to the Phoronomia, chapter 22 by Hermann. Varignon (see (Newton, 1822: I, note 215) refined the expression for $d p$ by constructing an orthogonal system of reference in which $m p=d z ; \quad m P=d y$ and $P p=d s$ is the arc differential. Since the triangles $p P m$ and $P S Q$ are similar, it is $d s: d y=z: p$, namely $p=\frac{z d y}{d s}$. The fluxion (derivative) of this expression is:

\footnotetext{
${ }^{25}$ Newton, 1822: I, pp. 81-82.
}

$$
d p=\frac{d z \cdot d y \cdot d s+z \cdot d s \cdot d^{2} y-z \cdot d y \cdot d^{2} s}{d s^{2}}
$$

Since $v=\frac{d p}{p^{3} d z}=\frac{d p \cdot d s^{3}}{z^{3} \cdot d y^{3} \cdot d z}$ and $p=\frac{z d y}{d s}$, one concludes that

$$
v=\frac{d z \cdot d y \cdot d s^{2}+z \cdot d s^{2} \cdot d^{2} y-z \cdot d y \cdot d s \cdot d^{2} s}{z^{3} \cdot d y^{3} \cdot d z}
$$

Through an easy passage, it is possible to express the value of the radius of the osculating circle (note 216) as

$$
r=\frac{z \cdot d z \cdot d s^{2}}{d z \cdot d y \cdot d s+z \cdot d s \cdot d^{2} y-z \cdot d y \cdot d^{2} s}
$$

Here the commentators add an interesting mathematical consideration: if the centre of the forces $S$ is posed ad infinitum, it is easy to see that the quantity $d z \cdot d y \cdot d s$ is infinitesimal in respect to $z \cdot d s \cdot d^{2} y$ and $z \cdot d y \cdot d^{2} s$, so that one obtains

$$
r=\frac{d z \cdot d s^{2}}{d s \cdot d^{2} y-d y \cdot d^{2} s}
$$

This formula, the commentators add, is hence valid for the radius of the osculating circle when the ordinates $S P$ are mutually parallel and when they are perpendicular to another straight line assumed as the other coordinate-axis. The last formula is exactly the one we use nowadays for the radius of the osculating circle. In fact, it is

$$
r=\frac{\left[(\dot{x})^{2}+(\dot{y})\right]^{3 / 2}}{|\dot{x} \ddot{y}-\dot{y} \ddot{x}|}
$$

And this formula is obtained from the previous one posing $x$ $=\mathrm{z}$ and $d s=\sqrt{(\dot{x})^{2}+(\dot{y})^{2}}$.

\section{Example 2. The Commentators' Treatise on Conic Sections: A Theorem on Hyperbola}

The addiction concerning the conic sections (Newton, 1822: I, pp. 86-102) is surely one of the most conspicuous interventions of the commentators to Newton's text. The aim is to provide a sort of handbook in which the properties of the conics useful to understand the Principia without resorting to the direct reading of Apollonius' work are referred. By the way the commentators quote the exact reference to Apollonius for every proposition they are proving, while Newton often writes simply "this derives from conics", without any further reference. The treatise is divided into four parts: 1) general properties of conics sections (Newton, 1822: I, pp. 86-92); 2) hyperbola (Newton, 1822: I, pp. 92-96); 3) ellipsis (Newton, 1822: I, pp. 96-100); 4) parabola (Newton, 1822: I, pp. 100-102). There are many interesting aspects, in particular: a) many properties are treated with a projective approach; b) trigonometric and, still more important, infinitesimal concepts are used, while this is not the case in Apollonius. We will deal with a demonstration showing the aspect b) and also developing a comparison with Apollonius' original proof. The proposition we analyse is the theorem 1 De Hyperbola (Newton, 1822: I, pp. 92-93). It sounds like this: "All lines drawn from the intersection of the asymptotes with a given angle are diameters of the hyperbola. Their part 


\section{P. BUSSOTTI, R. PISANO}

comprehended between the two sides of the hyperbola is told transverse diameter and it is divided into two equal parts by the intersecting point of the asymptotes, that hence is called the centre of the hyperbola. The segments of tangent drawn in the two vertices of the diameter and comprehended among the asymptotes are equal and parallel and are divided into two equal parts by that diameter. Hence they are told conjugate tangents to the diameter”. The proof is conceived in this manner (Figure 8):

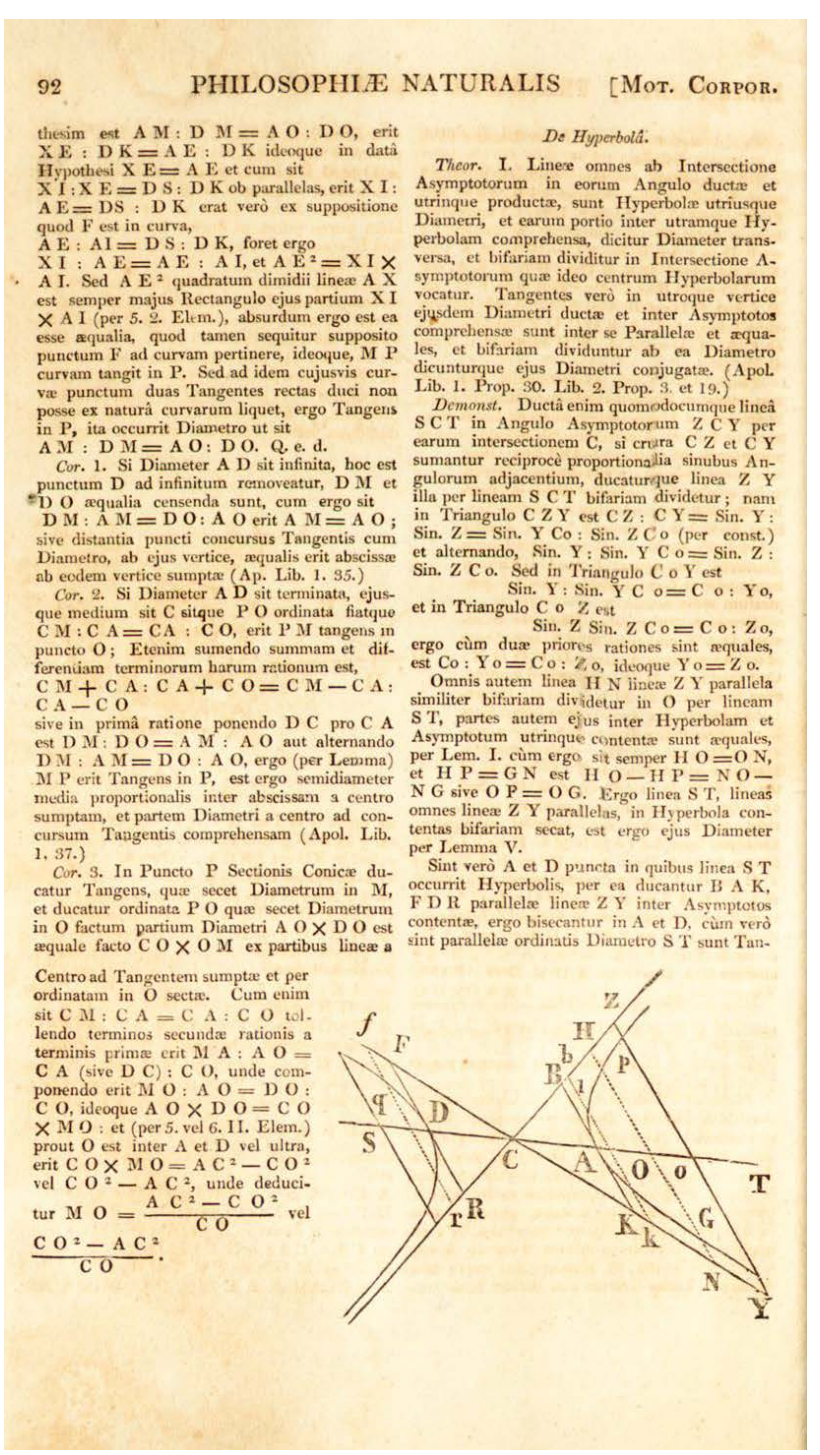

Figure 8.

Commentators' treatise on conic sections: the first theorem on hyperbola $^{26}$.

Let $F Y$ and $Z R$ be the asymptotes and let $S C T$ a straight line drawn through their intersection point $C$. Let us assume the lines $C Z$ and $C Y$ mutually proportional to the sins of the angles $o \hat{C} Y$ and $Z \hat{C} o$ respectively. Given this construction, the segment $Z Y$ is divided into two equal parts by SCT. For, let us consider the triangle $C Z Y$. It holds

$$
C Z: C Y=\sin \hat{Y}: \sin \hat{Z}=\sin o \hat{C} Y: \sin Z \hat{C} o
$$

Therefore

$$
\sin \hat{Y}: \sin o \hat{C} Y=\sin \hat{Z}: \sin Z \hat{C} o
$$

On the other hand, in the triangle $C o Y$, it is

$$
\sin \hat{Y}: \sin o \hat{C} Y=C o: Y o
$$

And in the triangle $\mathrm{CoZ}$, it is

$$
\sin \hat{Z}: \sin Z \hat{C} o=C o: Z o
$$
that

Therefore, on the basis of 17), we deduce from 18) and 19)

$$
\text { Co }: Y o=C o: Z o
$$

Namely $Y o=Z o$.

This proposition is valid for a complete system of lines parallel to $Z Y$, that is for lines as $H N, b k$ and so on. On the other hand, in Lemma I (Newton, 1822: I, pp. 87-88) of the same treatise on the conics, the commentators had proved that, given a hyperbola, and drawn a straight line between the two asymptotes, the two parts comprehended between the hyperbola and the asymptotes are equal. This proves the first part of the theorem. Let us consider for example the line $H O N$, for the already exposed reasoning $H O=O N$, for Lemma I, $H P=G N$, hence $P O=O G$. This means exactly that $S C T$, dividing into two equal parts the system of lines whose direction is $Z Y$, is a diameter conjugated to that direction (Lemma $\mathrm{V}$ of the treatise). With this it is not yet proved that $C A=C D$ and that, hence, $C$ is the centre of the hyperbola. This will be the last step of the demonstration.

Let $A$ and $D$ be the points in which the line SCT touches the hyperbola. Let us trace the lines $B A K$ and $F D R$, parallel to the system of lines $Z Y, H N, b k$ and so on. Since they are parallel to the ordinates $\mathrm{Zo}, \mathrm{HO}$, etc to the diameter $\mathrm{DA}$, they are the tangents in the vertices $A$ and $D$ (because of the Lemma IV of the treatise on conics). It is first necessary to prove that $B K=F R$. The commentators reason in this manner: let us trace the parallels bik, fqr. The commentators use the words "ipsis proximae,27 (that can be translated as "infinitely near to them") to the two tangents. Because of the above mentioned Lemma I, it is

$$
f q \cdot q r=b i \cdot i k
$$

Now, let us tend the two lines bik and fqr respectively to the tangents $B A K$ and $F D R$ and "tandem", namely "at the end" one has $f q=F D ; q r=R D ; b i=B A ; k i=K A$, so that

$$
F D \cdot R D=B A \cdot K A
$$

Furthermore $F D=D R$ and $B A=K A$ (because $D A$ is a diameter), hence $F D^{2}=B A^{2}$ and $D R=F D=B A=K A$. Finally the triangles $C A K$ and $C D F$ are similar, so that

$$
C A: C D=K A: F D
$$

but, since $K A=F D$, it is $C A=C D$. This proves completely the theorem.

In this demonstration the concept of limit plays an essential role because it allows the replacements from Equation (21) to Equation (22). The limit is seen in a typical Newtonian manner, that is as a process in motion that brings at the end from the secants $f r$ and $b k$ infinitely near at the tangents $F R$ and $B K$ themselves and this implies that the least reason of the secants (when they become tangents) is a reason of equality. This proof is a good example of how the commentators, trying to remain faithful the style of Newton himself, inserted a passage to

\footnotetext{
${ }^{27}$ Newton, 1822: I, p. 93, first column, line 4.
} 
the limit inside a substantially synthetic geometrical reasoning.

The commentators refer that the exposed propositions coincides with three propositions by Apollonius: I, 30 and II, 3 and 19. It is interesting to compare Apollonius' demonstrations with those of the JE. This gives the idea how different are the proves of the same propositions when different mathematical concepts are introduced. In this sense the JE is also a fundamental contribution for history of mathematics.

The proposition I, 30 is: "In a hyperbola or an ellipsis any chord through the centre is bisected at the centre" ${ }^{, 28}$. To prove this proposition, Apollonius proceeds in a completely different way than the commentators, without resorting to the notion of asymptote, but to a series of other propositions and definitions (Figure 9. Inside the figure the imagine referred to the hyperbole is the one on the left side):

Let $P P^{\prime}$ be the diameter, $C$ the centre and $Q Q^{\prime}$ a chord passing through the centre. Let $Q V, Q^{\prime} V^{\prime}$ be the so called ordinates to the diameter $P P^{\prime}$. For the hyperbola (Ivi, prop. I, 21 , in its turn a consequence of the fundamental proposition I, 12 where the notion of latus rectum or parameter and transverse diameter are introduced for the hyperbola), and for the circle and the ellipsis, too, it holds that $Q V^{2}$ is proportional to $P V \cdot P^{\prime} V$. Therefore the identity holds

$$
P V \cdot P^{\prime} V: P^{\prime} V^{\prime} \cdot P V^{\prime}=Q V^{2}: Q^{\prime} V^{\prime 2}
$$

The triangles $C Q V$ and $C V^{\prime} Q^{\prime}$ are similar for construction, hence it is

$$
P V \cdot P^{\prime} V: P^{\prime} V^{\prime} \cdot P V^{\prime}=Q V^{2}: Q^{\prime} V^{\prime 2}=C V^{2}: C V^{\prime 2}
$$

For the hyperbola, decomposing one has

$$
C V^{2}-P V \cdot P^{\prime} V: C V^{2}=C V^{\prime 2}-P^{\prime} V^{\prime} \cdot P V^{\prime}: C V^{\prime 2}
$$

But $C V^{2}-P V \cdot P^{\prime} V=C P^{2}$. We stress that to reach this conclusion it is necessary that $P P^{\prime}$ is a diameter. For, $C V=C P+$ $P V$, hence the expression $C V^{2}-P V \cdot P^{\prime} V$ is equal to $(C P+P V)^{2}-P V \cdot P^{\prime} V$, that is

$$
C P^{2}+P V\left(P V+2 C P-P^{\prime} V\right)
$$

Of course $P V \neq 0$, but since $P P^{\prime}$ is a diameter and $C$ the centre of the hyperbola, it is $P^{\prime} V=2 C P+P V$, so that, it is $C V^{2}-P V \cdot P^{\prime} V=C P^{2}$. Since $C P^{2}=C P^{\prime 2}$, it is $C V=C V^{\prime}$ and for the parallels $Q V, Q^{\prime} V^{\prime}$, it follows $C Q=C Q^{\prime}$.

The proof of Apollonius (Figure 9) needs the concept of diameter (and the existence of, at least, one diameter), of centre and resorts to two previous proposition. There is no resort to infinitesimal reasoning (either in the proof of the proposition itself, as we have seen, or in that of I, 12 and I, 21).

The proposition II, 3 sounds: "If a straight line touch a hyperbola at $P$, it will meet the asymptotes in two points $L, L^{\prime}$; $L L^{\prime}$ will be bisected at $P$, and $P L^{2}=\frac{1}{4} p \cdot P P^{\prime \prime 29}$. The last part of this proposition concerns the parameter $p$, a concept that will be dealt with by the commentators in their theorems 2 and 3 , not in theorem 1. Apollonius' reasoning is the following (Figure 10):

if the tangent does not meet the asymptotes in the points $L, L^{\prime}$, let us take two segments

\footnotetext{
${ }^{28}$ Apollonius, 1896: p. 21.

${ }^{29}$ Apollonius, 1896: p. 56.
}

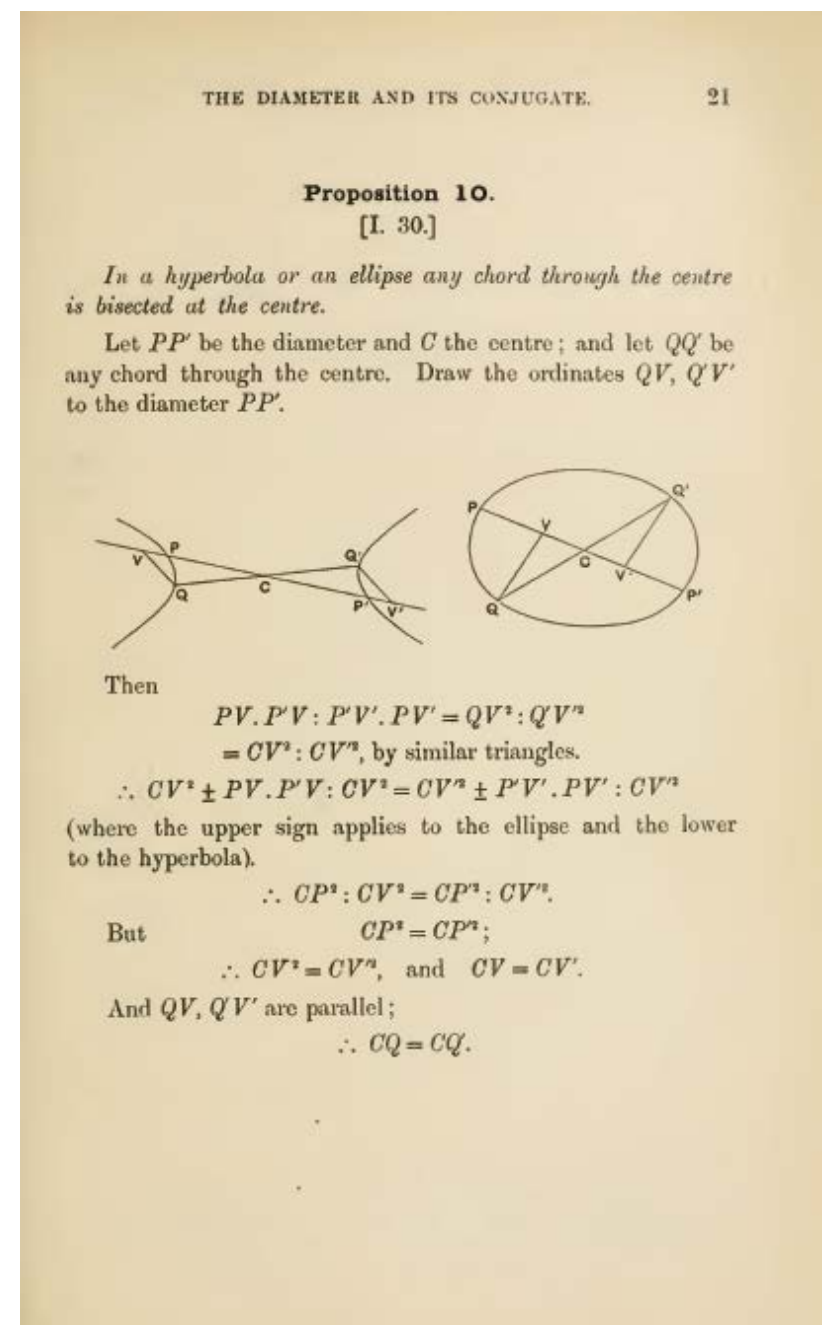

Figure 9.

Proposition I, 30 of Apollonius' Conics $^{30}$.

$$
P K=P K^{\prime}=\frac{1}{2} \sqrt{p \cdot P P^{\prime}} .
$$

Given this construction, the proposition II, 1 ensures that $C K$ and $C K^{\prime}$ are asymptotes, but proposition II, 2 shows that no straight line through $C$ within the angle between the asymptotes can itself be an asymptote. This absurdity implies that $K, K^{\prime}$ coincides with $L L^{\prime}$, and it is $P L=P L^{\prime}=\frac{1}{2} \sqrt{p \cdot P P^{\prime}}$. In the proposition II, 5 Apollonius proves that if the diameter of a parabola or of a hyperbola cuts a chord into two equal parts, the tangent at the vertex of that diameter is parallel to the chord divided into two equal parts. From here it is easy to prove (using the same symbols as the commentators) that

$$
D R=F D=B A=K A \text {. }
$$

The procedure of the commentators is different from Apollonius' who, particularly, introduces the concepts of diameter and of latus rectum (parameter) of a conic section (in our case the hyperbola) from the beginning, while the commentators introduce at first the concept of asymptote (which is postponed by

\footnotetext{
${ }^{30}$ Apollonius, 1896: p. 21.
} 


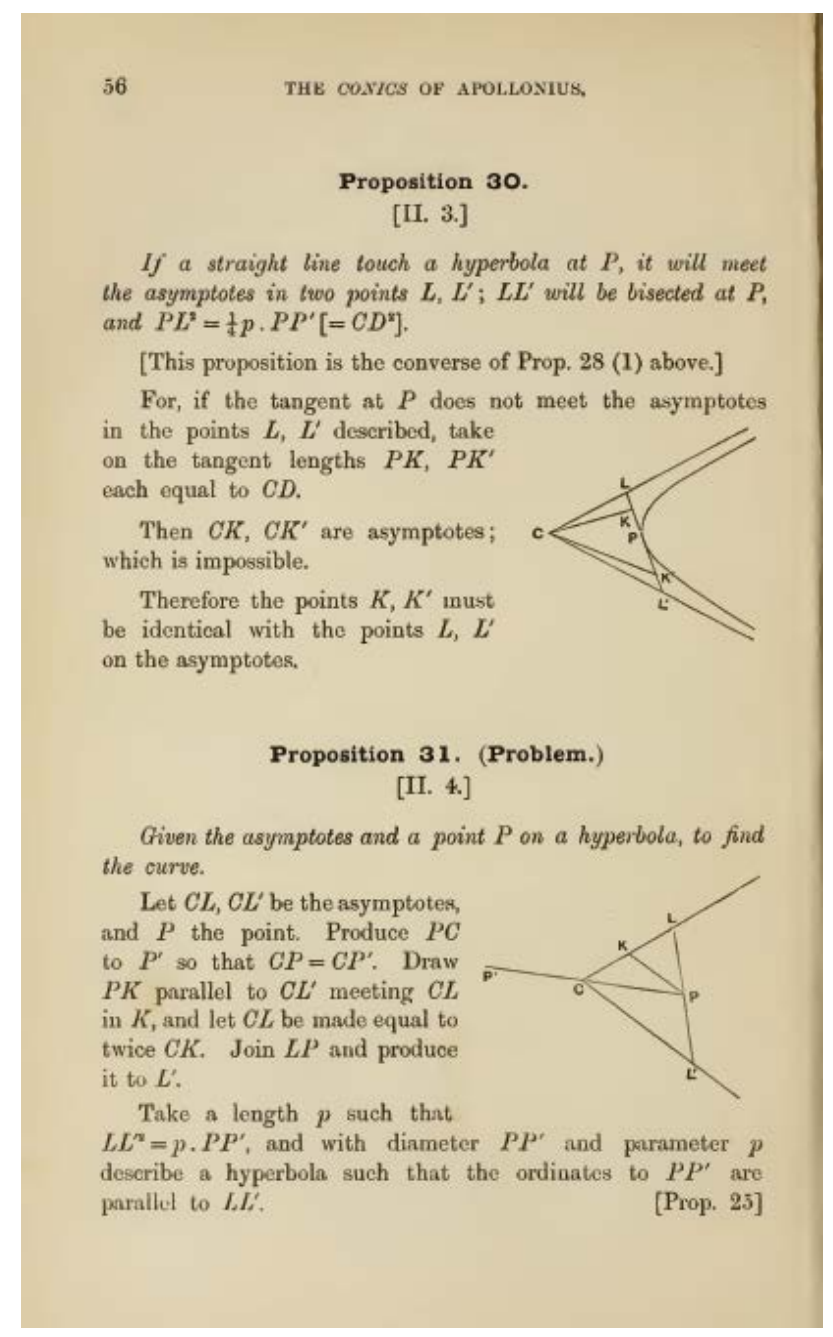

Figure 10.

Apollonius’ proposition II, 3. From Apollonius, 1896: p. 56.

Apollonius in the first proposition of the second book). This generates - as we have seen-a different way to prove the same propositions, also considering that Apollonius wants to provide a complete treatise on the conics, while the commentators want to show the properties useful to understand Newton's text. However the great difference between Apollonius and the commentators consists in one aspect: the use of the concept of limit and of the connected infinitesimal calculus in some part of the demonstrations, that simplifies otherwise difficult proofs. There are many examples; one of them concerns proposition II, 2, used, as we have seen, to prove the Proposition II, 3. The proposition II, 2 aims to prove that no straight line through the centre of a hyperbola within the angles can itself be an asymptote $^{31}$. With the concept of limit (a posteriori) it is enough to think that the

$$
\lim _{x \rightarrow 0} \frac{1}{x}=\infty \text { and that } \lim _{x \rightarrow \infty} \frac{1}{x}=0
$$

It is sufficient to refer to the first quadrant and to the equilateral hyperbola, because if a hyperbola is not equilateral the reasoning does not change from a conceptual point of view. Its

\footnotetext{
${ }^{31}$ Apollonius, 1896: p. 55.
}

meaning is: 1) when $x$ tends to 0 , the difference between the $y$-axis and the hyperbola can become smaller than every given value, if $x$ is - told intuitively-small enough; 2) the difference between the $x$-axis and the hyperbola can become smaller than any given value if $x$ tends to the infinity. Therefore every straight line inserted within the angles of the asymptotes through the centre will cut the hyperbola. Apollonius cannot use the concept of limit and hence, to prove the proposition II, 2 resorts to an elegant, but relatively complicated ad absurdum reasoning, based on a series of steps also exploiting previous propositions, as the reader can see in Figure $11^{32}$.

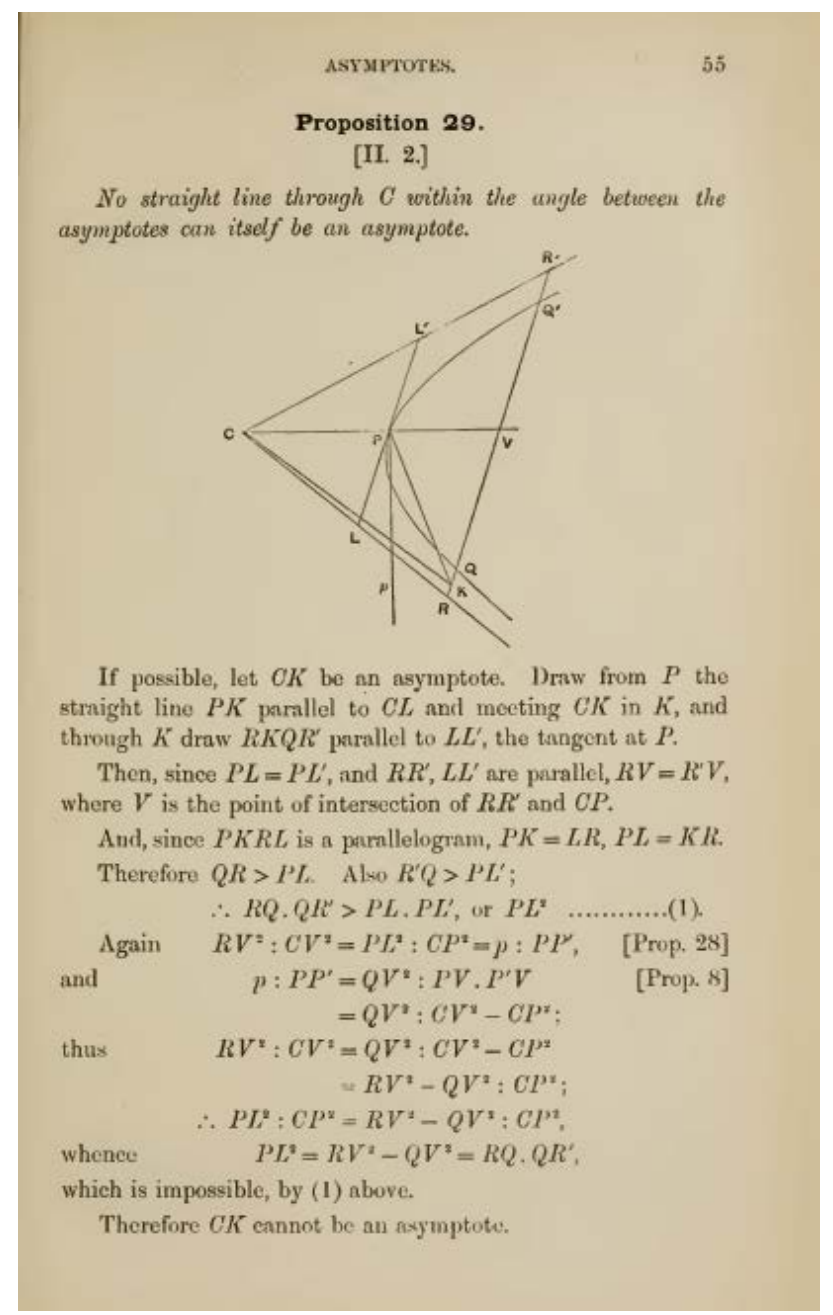

Figure 11.

Apollonius’ proposition II, 2. From Apollonius, 1896: p. 55.

On the other hand the resort to ad absurdum demonstrations is a typical procedure for the problem of insertions, when one cannot exploit directly the concept of limit. The case of the exhaustion method is typical. This should hence induce to a great prudence with regard to the idea that the ancients-and in particular Archimedes-possessed in nuce the concept of limit. Even if the concept of limit was not expressed in modern notation, as we have made, it was known and used by the commentators and, of course, by Newton himself, albeit the word limit

\footnotetext{
${ }^{32}$ In particular the propositions I, 21 (Apollonius, 1896: pp. 19-20) and II, 1
} (Apollonius, 1896: pp. 53-54). 
was not utilized by him, rather the expression "method of first ratios of nascent quantities and last ratios of vanishing quantities”, as well known. We have given a clear example of how Newton and the commentators used the concept of limit in the previous section 5.1. of this paper.

The other consideration in a comparison between the treatment of the conics in the XVII century and Apollonius' concerns the projective geometry, and in particular, the concept of ad infinitum point. Newton himself and the commentators use-even if not in a formalized manner-this notion. Let us think of the Scholium (Newton, 1822: I, pp. 180-190) inserted in the section V by Newton, where he explicitely writes: "Asymptotos autem pro tangente habenda est, et eius terminus infinite distans (si ita loqui fas sit) pro puncto contactus" (Newton, 1822: 1, p. 181, lines 2-3). In this sense the work by La Hire where many results by Desargues are written in a more comfortable form than Desargues', exerted a certain influence on Newton and on the commentators. For, La Hire is mentioned.

\section{Example 3. Lemma XXVIII: Ovals and Equations}

Let us finally analyse one of the most genial propositions and reasoning exposed in the Principia, but maybe in the whole history of science and mathematics: the Lemma XXVIII in the $6^{\text {th }}$ section of the Principia. Newton proves that: "there is no oval figure whose area, cut off by right lines at pleasure, can be universally found by means of equations of any number of finite terms and dimensions" (translation drawn from Newton, 1729: I, p. 145; Newton, 1822: I, pp. 203-207). Newton does not define the concept of oval, but it is clear that he is referring to never self-intersecting curves that are continuous, whose arc is never a segment of a straight line and with a finite curvature. The conclusions drawn by Newton from this lemma are that, given the time, it is possible to find the place of a body moving along an elliptic trajectory: 1) either by means of transcendental curves as the trochoid (Newton, 1822: I, Section VI, prop. XXXI, pp. 209-212); 2) or by methods of approximations (Newton, 1822: I, Section VI, Scholium, pp. 213-225). Therefore he was mainly interested in conclusions concerning astronomy, and this is only natural taking into account the scopes of the Principia. However, as Pesic remarks ${ }^{33}$, this lemma is fundamental for theoretical mathematics, too, because one of its most evident consequence is that the area of the circle-that is an oval-cannot be expressed as the solution of an algebraic equation of finite degree whose coefficients are rational in respect to the radius of the circle. It is well known that the problem of the transcendence of $\pi$ is very complicated and was solved only at the end of the $19^{\text {th }}$ century through an analytical method (Lindemann, 1882). Nevertheless, the reasoning by Newton shows intuitively that $\pi$ is transcendent in respect to the radius. This lemma represents hence a great occasion to discuss what intuitive means in mathematics and in what sense Newton's genial proof can be considered rigorous and inside which limits it can be considered valid. All these are important epistemological and methodological questions with which we cannot deal with in this context, but that, certainly, have to be posed. Let us now see the bases of Newton's reasoning and some interventions of the commentators. Newton resorts neither to figures nor to symbols. The steps are the following:

1) given a point $P$ in an oval, a line $r$ rotating with a uniform motion around $P$ and a mobile point starting from $P$ and mov${ }^{33}$ Pesic, 2003, chapter 4 presents an interesting discussion and analysis of
this Newtonian lemma. ing along $r$ with a speed which is proportional to the square of the distance (calculated along $r$ ) between $P$ and the oval, the mobile point describes a spiral. Given these conditions, a proportionality exists between sectors of the oval area and points of the spiral, that represent the distance from $P$ along $r$ of the mobile point. Hence if a portion of the oval area cut off by the line $r$ can be found by a finite equation, then the intersection of the line $r$ with the spiral will be found through a finite equation of the same degree, as well;

2) Every line cuts the spiral in an infinite number of points;

3) The solutions of an irreducible equation indicating the intersections between two lines allow to find all these intersections, therefore such equation has the same degree as the number of intersections between the two lines;

4) Thus, the equation indicating the intersections between a straight line and a spiral has an infinite degree;

5) As a consequence the degree of the equation indicating the area of the oval figure has an infinite degree, too.

Every step is justified in words and Newton is, as often, quite synthetic. We will consider the intervention of the commentators as to the first step, that is the basis of Newton's reasoning and that, in a sense, is the most refined part of this proof.

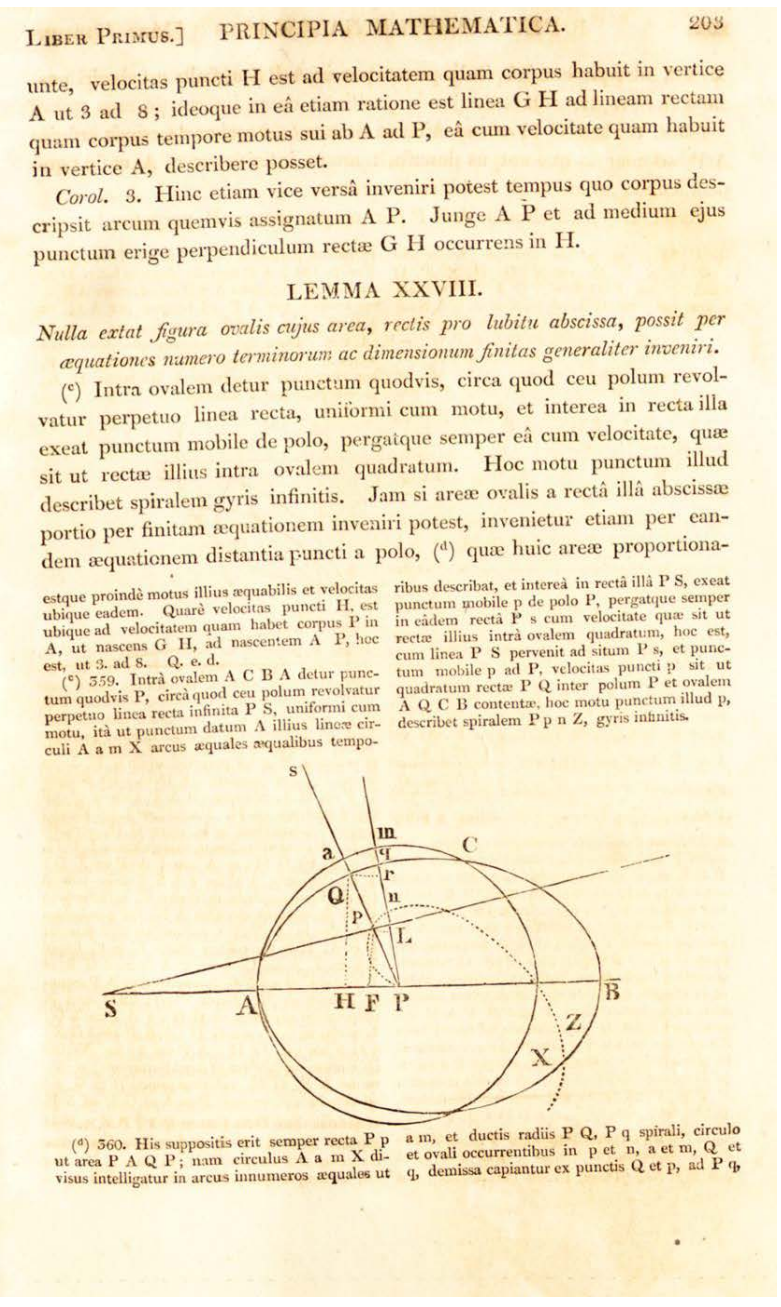

Figure 12.

Newton's Lemma XXVIII and commentators' demonstration ${ }^{34}$. 
The commentators deal with the first part of Newton's demonstration in the notes 359 and 360 (pp. 203-204; see Figure 12). Let $A C B A$ be the oval and $P$ the pole around which the line $S P$ (we have indicated such line as $r$ ) rotates with a uniform motion, so that the point $A$, intersection between the oval and $r$, and also belonging to the circle $\operatorname{Aam} X$ (whose centre is $P$ and whose radius is $P A$ ) describes equal arcs of such circle in an equal time. The different positions of $r$ are indicated by $P A, P a$, $P m, \ldots$ Let $p$ be the mobile point that gets out from $P$, whose position is always on the rotating line $r \equiv S P$ and whose speed is as the square of the distance between the point $P$ and the intersection of $r$ with the oval (for example when $r$ is in the position PpQa such distance is $P Q$ ). The spiral is the dotted line. The fundamental passage for the demonstration is that the segment $P p$ (with $p$ belonging to the spiral) is always proportional to the area of the oval sector $P A Q$. The explanation given by the commentators is the following: let us suppose the circle AamX divided into infinitesimal equal arches as $a m$. Let $P a$ and $P m$ be two radiuses cutting respectively the spiral in $p$ and $n$ and the oval in $Q$ and $q$. Let $Q r$ and $P L$ be perpendicular to $P q$. Now a very important consideration: in the same time in which the point $a$ covers the arch am (that is, we add, in the time in which the line $r$ passes from the position $\mathrm{Pa}$ to the position $\mathrm{Pm}$ ), the mobile point has moved in the spiral from the point $p$ to the point $n$, namely the segment $L n$. Brief our explanation of the passage: in the time $t_{1}$ let the mobile point be in the point $p$, belonging to the spiral and to the mobile line $r$. In the time $t_{2}$, this mobile point will be in the point $n$, belonging to the spiral and to the line $r$ in its new position. Since $p L$ is perpendicular to $P m$, then if we consider the motion of the point on the mobile straight line $r$, in the time interval $\left(t_{1}, t_{2}\right)$ the segment $L n$ is covered. Now, the commentators continue, since the speed of the line is constant, the segment $L n$ will be at the nascent arch $a m$ as the square of $P Q$ (since the speed of the mobile point is, by hypothesis, proportional to the square of the distance $P$-oval). Furthermore, the triangles Pam and $P Q r$ are similar and hence it is

$$
P a: P Q=a m: Q R,
$$

from which, it follows $Q r=\frac{P Q \cdot a m}{P a}$. Since $P Q r$ is an infinitesimal sector, its area is

$$
\frac{1}{2} Q R \cdot P Q=\frac{P Q^{2} \cdot a m}{2 P a} .
$$

The quantities am and $2 \mathrm{~Pa}$ are constant, the oval nascent (infinitesimal) sector $P Q q$, which is the fluxion of the oval area $P A Q$, is proportional to $P Q^{2}$ and hence to $L n$, which is the fluxion of the line $P p$. Therefore the all fluent area $P A Q$ (that is the integral of the infinitesimal oval arch $P Q q$ ) is as the whole fluent line $P p$. This is the clear explanation of the commentators (plus some additions of ours we have underlined) that makes the first and fundamental part of Newton's reasoning clear. Furthermore it shows a significant example of how, at that time, the concepts of fluxion and fluent were used. This is a classical example of how the calculus can be useful in a substantially geometrical reasoning because the basis and the structure of Newton's argumentation and proof in completely geometrical, the calculus plays and important role in some phases of the demonstration, but its basis and inspiration are geometrical.

\section{Conclusion}

\section{Final Remarks on Science as Cultural Phenomenon within the Society}

The Science from ancient times (generally speaking) to nowadays, usually built a perception within society according with the idea that science is synonymous of progress \& modernity; especially during period of materializations. We know that anomalies, inversions and controversies also belong up cited erroneously so called progress \& modernity. Then it would interesting to investigate author per author to understand effetely how science worked and how society worked ${ }^{35}$, i.e., the concept of civilization (Buchwald and Feingold).

Newton's science certainly produced a strong impact on humanity, particularly on the Western civilization both concerning the scientific and supernatural background of the laws of nature, including mathematical interpretations of phenomena like nonphysical laws; sometimes outside the context of the theory (i.e. providence, religion etc.). Certainly by combining scientific traditions and contributions of scholars, i.e., like Copernicus, Kepler, Galileo and Descartes (Schuster, 2000, 2013) he provided to create a scientific framework based on an adequate mathematics (and geometry) for interpreting terrestrial and celestial physical phenomena which, a priori, were geometrically idealized to be easily citizens in his new revolutionary, $a$ posteriori so called, mathematization of the nature. On the other hand, a parallel problem related to a dialogue as communication-language between specialists (advanced and applied researches) and non-specialists (versus a scientific civilization) is a trouble matter, i.e. how is it possible to pass from science to technique and to technologies? And who was really able to be mediator in any other context of society?

Finally the popularization of Newton's Jesuit editions is a historical scientific attestation. The idea that a human mind can produce an intellectual revolution within science and its approaches (methods and methodologies also integrated with contradictions and criticisms) strongly crossed like a paradigm both in the history of sciences and disciplines-literatures (reasonings, early enlightenment, positivism, etc.). Newton's science and Newtonian science in the history made comprehensible both the science according his physical paradigm (mechanics) and sciences alternative to his paradigm, i.e. Lazare Cantot's mechanics, geometry and mathematics (Carnot, 1786, 1803a, 1803b, 1813; Gillispie \& Pisano, 2013; Pisano \& Capecchi, 2013; Pisano, 2013). In this sense the birth of modern science and science in general, in all its contradictions, anomalies and developments certainly also represent a cultural phenomena.

\section{Final Remarks on Newton's Jesuit Editions}

This paper has an introductory character for a research we are carrying out. The final purposes of the research are:

1) A clear delineation of the relations between mathematics and physics inside the Principia. In other terms: how the particular way in which Newton used geometry and infinitesimal procedures influenced his physics;

2) The comprehension why and how Newton's mathematical methods were progressively, but rapidly, replaced by more analytical methods. This second part has profound connections with the development of science and mathematics in the soci-

\footnotetext{
${ }^{35}$ Our research on the fourth volumes is in progress.
} 
ety.

The Jesuit Edition will be the fundamental text to which we will refer because the commentators enter deeply into Newton's mathematical argumentations. Conspicuous part of our work will consist in explaining the procedures used by Newton and the methods followed by the commentators in their notes. This will make it clear Newton's way of thinking and the passage to his mentality to the purely analytical one, that was acquired definitively with Lagrange's work. A part from the two general purposes that we exposed, we also aspired to clarify some elliptical and difficult Newton's procedures, relying upon the explicative note of the commentators. This could be a useful contribution to history of physics and mathematics. In this paper we have given a synthetic model of our future research.

\section{Acknowledgements}

We want to express our gratitude to anonymous referees for precious comments and helpful suggestions.

We would like to thank the Alexander von Humboldt Foundation for Funding of Research and Writing in München (20032005 with Prof. Dr. Menso Folkerts) and Berlin (2013-2014 with Prof. Dr. Eberhard Knobloch) allowing one of us to better go into Keplerian subject of our historical-epistemological research programme concerning the relationships between physics and mathematics in 13th-18th context: Fibonacci, Leonardo, Tartaglia, Kepler, Galileo, Descartes, Newton, Torricelli.

\section{REFERENCES}

's Gravesande, W. J. (1720-1721). Physices elementa mathematica, experimentis confirmata, sive introductio ad philosophiam Newtonianam (two volumes). Leiden: Vander \& Vander, Lugduni Batavorum.

Agassi, J. (1978). The ideological import of Newton. Vistas in Astronomy, 22, 419-430. http://dx.doi.org/10.1016/0083-6656(78)90032-6

Agostino, Sd' (1988). Boscovich’s reception of Newton’s legacy. In M. Bossi, \& P. Tucci (Eds.), Bicentennial commemoration of R. G. Boscovich (pp. 28-45). Milano: Edizioni Unicopli.

Ahnert, T. (2004). Newtonianism in early Enlightenment Germany, c. 1720 to 1750: Metaphysics and the critique of dogmatic philosophy. Studies in History and Philosophy of Science, 35, 471-491. http://dx.doi.org/10.1016/j.shpsa.2004.06.003

Allen, L. D. (1998). Physics, frivolity and "Madame Pompon-Newton": The historical reception of the Marquise du Chatelet from 1750 to 1996. Doctoral Dissertation, Cincinnati: University of Cincinnati.

Apollonius of Perga (1896). Treatise on conic sections. Edited in modern notation with introductions including an essay on the earlier history of this subject by T. L. Heath, M. A. Sometime fellow of Trinity College. Cambridge: Cambridge University Press.

Arthur, R. T. W. (1995). Newton's fluxions and equably flowing time. Studies in History and Philosophy of Science, 26, 323-351.

http://dx.doi.org/10.1016/0039-3681(94)00037-A

Axtell, J. L. (1965). Locke's review of the principia. Notes and Records of the Royal Society, 20, 152-161.

http://dx.doi.org/10.1098/rsnr.1965.0013

Baillon, J. F. (2004). Early eighteenth century Newtonianism: The Huguenot contribution. Studies in History and Philosophy of Science, 35, 533-548. http://dx.doi.org/10.1016/j.shpsa.2004.06.006

Barber, W. H. (1979). Voltaire et Newton. Studies on Voltaire and the Eighteenth Century, 179, 193-202.

Barker, P. (2006) New work in early modern science. Centaurus, 48, 1-2. http://dx.doi.org/10.1111/j.1600-0498.2006.00037.x

Beaver, D. de B. (1987) Textbooks of natural philosophy: The beautification of technology. In Berggren and goldsein (pp. 203-213).

Berggren, J. L., \& Goldsein, B. R. (1987). From ancient omens to statistical mechanics. Copenhagen: University Library.
Biagioli, M. (1998). The scientific revolution is undead. Configurations, 6, 141-148. http://dx.doi.org/10.1353/con.1998.0011

Biagioli, M. (1999). The science studies reader. New York and London: Routledge.

Blay, M. (1983). La conceptualisation newtonienne des phénomènes de la couleur. Paris: Vrin.

Boss, V. I. (1972). Newton and Russia, the Early Influence 1698-1796. Cambridge, Mass.: Harvard University Press.

Bourdieu, P. (1975, 1999) The specificity of the scientific field and the social conditions of the progress of reason. In Biagioli (pp. 31-50), First published in Social Science Information, 14, 19-47.

Bricker, P., \& Hughes, R. I. G. (1990). Philosophical perspectives on Newtonian science. Cambridge-MA-London: The MIT Press.

Briggs, E. R. (1983). English socinianism around Newton and Whiston. Studies on Voltaire and the Eighteenth Century, 216, 48-50.

Brockliss, L. W. B. (1992). The scientific revolution in France. In R. Porter, \& M. Teich (Eds.), The scientific revolution in France (pp. 55-89). Cambridge: Cambridge University Press.

Buchwald, J. Z., \& Feingold, M. (2011). Newton and the origin of civilization. Princeton, NJ: The Princeton University Press.

Bussotti, P., \& Pisano, R. (2013). On the conceptual frames in René Descartes' physical works. Advances in Historical Studies, 2, 106125. http://dx.doi.org/10.4236/ahs.2013.23015

Calinger, R. S. (1968). The Newtonian-Wolffian confrontation in the St. Petersburg Academy of Sciences (1725-1746). Journal of World History, 11, 417-435.

Calinger, R. S. (1969). The Newtonian-Wolffian controversy: 17401759. Journal of the History of Ideas, 30, 319-330. http://dx.doi.org/10.2307/2708560

Carnot, L. (1786). Essai sur les machines en général. Dijon: Defay.

Carnot, L. (1803a). Principes fondamentaux de l'équilibre et du movement. Paris: Deterville.

Carnot, L. (1803b). Géométrie de position. Paris: Duprat.

Carnot, L. (1813). Réflexions sur la métaphysique du calcul infinitésimal. Paris: Courcier.

Carriero, J. (1990). Newton on space and time: Comments on J. E. McGuire (pp. 109-133). In P. Bricker, \& R. I. G. Hughes (Eds.), Philosophical perspectives on Newtonian science (pp. 109-133). Cambridge, MA, London: The MIT Press.

Casini, P. (1988). Newton's principia and the philosophers of the enlightenment. Notes \& Records of the Royal Society, 42, 35-52.

Champion, J. A. I. (1999) Acceptable to inquisitive men: Some Simonian contexts for Newton's biblical criticism, 1680-1692. In J. E. Force, \& R. H. Popkin (Eds.), Newton and religion: Context, nature, and influence (pp. 77-96). Dordrecht: Kluwer Academic Publisher.

Chandrasekhar, S. (1995). Newton's principia for the common reader. Oxford: Clarendon Press.

Châtelet, (du) É. (1759). Isaac Newton. Principes mathématiques de la philosophie naturelle par feu madame la Marquise du Châtelet. Paris: Desaint et Saillant.

Clark, W. (1992). The scientific revolution in the German nations. In R. Porter, \& M. Teich (Eds.), The scientific revolution in France (pp. 55-89). Cambridge: Cambridge University Press.

Clark, W. (1997). German physics textbooks in the Goethezeit. History of Science, 35, 219-239, 295-363.

Clark, W., Golinski, J., \& Schaffer, S. (1997). The sciences in Enlightened Europe. Chicago: The University of Chicago Press.

Clarke, J. ([1730], 1972). Demonstration of some of the principal sections of Sir Isaac Newton's principle of natural philosophy. New York: Johnson Reprint Corporation.

Cohen, I. B. (1990). Newton's method and Newton's style. In F. Durham, \& D. Purrington (Eds.), Some truer method (pp. 15-17). New York: Columbia University Press.

Coudert, A. P. (1999). Newton and the Rosicrucian Enlightenment. In J. E. Force, \& R. H. Popkin (Eds.), Newton and religion: Context, nature, and influence (pp. 17-43). Dordrecht: Kluwer Academic Publisher.

Craig, J. (1963). Isaac Newton and the counterfeiters. Notes and Records of the Royal Society, 18, 136-145. http://dx.doi.org/10.1098/rsnr.1963.0017 
Crasta, F. M. (1989). Aspects of eightenth-century cosmology. Memorie della Società Astronomica Italianam, 60, 823-836.

Cunningham, A., \& Williams, P. (1993). Decentring the 'big picture': The Origins of Modern Science and the modern origins of science. British Journal for the History of Science, 26, 407-432. http://dx.doi.org/10.1017/S0007087400031447

Darrigol, O. (2005). Worlds of flow: A history of hydrodynamics from the Bernoullis to Prandtl. Oxford: The Oxford University Press.

Darrigol, O. (2012). A history of optics: From Greek antiquity to the nineteenth century. Oxford: The Oxford University Press.

De Gandt, F. (1995). Force and geometry in Newton's Principia. Princeton, NJ: Princeton University Press.

Dear, P. (1987). Jesuit mathematical science and the reconstitution of experience in the early seventeenth century. Studies in the History and Philosophy of Science, 18, 133-175. http://dx.doi.org/10.1016/0039-3681(87)90016-1

Dear, P. (1995). Discipline \& experience. The mathematical way in the scientific revolution. Chicago: The University of Chicago Press. http://dx.doi.org/10.7208/chicago/9780226139524.001.0001

Dear, P. (1998). The mathematical principles of natural philosophy: toward a heuristic narrative for the scientific revolution. Configurations, 6, 173-193. http://dx.doi.org/10.1353/con.1998.0015

Desaguilers, T. (1717). Phisico-mechanical lectures. [Printed for the Author and sold by him]. London: Richard Bridger and William Vream.

Ducheyne, S. (2005). Mathematical models in Newton's Principia: A new view of the 'Newtonian Style'. International Studies in the Philosophy of Science, 19, 1-19. http://dx.doi.org/10.1080/02698590500051035

Durham, F., \& Purrington, R. D. (1990). Some Truer Method. New York: Columbia University Press.

Elliott, P. (2000). The birth of public science in the English provinces: Natural philosophy in Derby, c. 1690-1760. Annals of Science, 57, 61-100. http://dx.doi.org/10.1080/000337900296308

Fara, P., \& Money, D. (2004). Isaac Newton and Augustan Anglo-Latin poetry. Studies in History and Philosophy of Science, 35, 549-571. http://dx.doi.org/10.1016/j.shpsa.2004.06.007

Feingold, M. (2004). The Newtonian Moment, Isaac Newton and the making of modern culture. Oxford: Oxford University Press.

Fellmann, E. A. (1988). The Principia and continental mathematicians. Notes \& Records of the Royal Society, 42, 13-34

Ferrone, V. (1982). Scienza, natura, religione. Mondo newtoniano e cultura italiana nel primo Settecento. Napoli: Jovene.

Force, J. E. (1983). Some eminent Newtonians and providential geophysics at the turn of the 17th century. Earth Sciences History, 2, 4-10.

Force, J. E. (1985). William Whiston, honest Newtonian. Cambridge: Cambridge University Press.

Force, J. E. (2004). Providence and Newton's Pantokrator: Natural law, miracles, and Newtonian science. In J. E. Force, \& S. Hutton (Eds.), Newton and Newtonianism: New studies (pp. 65-92). Dordrecht: Kluwer Academic Publishers.

Force, J. E., \& Hutton, S. (2004). Newton and Newtonianism: New studies. New York, Boston Dordrecht, London, Moscow: Kluwer Academic Publishers. http://dx.doi.org/10.1007/1-4020-2238-7

Force, J. E., \& Popkin, R. H. (1999). Newton and religion. context, nature and influence. New York, Boston, Dordrecht, London, Moscow: Kluwer Academic Publishers.

Friesen, J. (2006). Hutchinsonianism and the Newtonian Enlightenment. Centaurus, 48, 40-49.

http://dx.doi.org/10.1111/j.1600-0498.2006.00033.x

Gascoigne, J. (1988). From Bentley to the Victorians: The rise and fall of British Newtonian natural theology. Science in context, 2, 219256. http://dx.doi.org/10.1017/S0269889700000582

Gaukroger, S. (1986). Philosophical responses to the New Science in Britain, 1644-1799. A survey of texts. Metascience: An International Review Journal for the History, Philosophy and Social Studies of Science, 4, 60-71.

Gillispie, C. C., \& Pisano, R. (2013). Lazare and Sadi Carnot. A scientific and filial relationship. Dordrecht: Springer. http://dx.doi.org/10.1007/978-94-007-4144-7
Goldish, M. (1998). Judaism in the theology of sir Isaac Newton. Dordrecht: Kluwer Academic Publishers.

http://dx.doi.org/10.1007/978-94-017-2014-4

Goldish, M. (1999). Newton's of the church: Its contents and implication. In J. E. Force, \& R. H. Popkin (Eds.), Newton and religion: Context, nature, and influence (pp. 145-164). Dordrecht: Kluwer Academic Publisher.

Golinski, J. (1998). Making natural knowledge: Constructivism and the history of science. Cambridge: Cambridge University Press.

Gregory, D. (1702). Astronomiae physicae et geometricae elementa. Oxford: Theatre Sheldonian.

Guerlac, H. (1981). Newton on the continent. Ithaca, New York: Cornell University Press.

Guerrini, A. (1985). James Keill, George Cheyne, and Newtonian physiology, 1690-1740. Journal of the History of Biology, 18, 247-266. http://dx.doi.org/10.1007/BF00120111

Guicciardini, N. (1989). The developments of Newtonian Calculus in Britain, 1700-1800. Cambridge: Cambridge University Press. http://dx.doi.org/10.1017/CBO9780511524745

Guicciardini, N. (1998). Did Newton use his calculus in the Principia? Centaurus, 40, 303-344.

http://dx.doi.org/10.1111/j.1600-0498.1998.tb00536.x

Guicciardini, N. (1999). Reading the Principia. The debate on Newton's mathematical methods for natural philosophy from 1687 to 1736. Cambridge: Cambridge University Press. http://dx.doi.org/10.1017/CBO9780511524752

Guicciardini, N. (2002). Analysis and synthesis in Newton's mathematical work. In I. B. Cohen, \& G. Smith (Eds.), Companion to Newton (pp. 308-328). Cambridge: Cambridge University Press.

Guicciardini, N. (2004). Dot-Age: Newton's legacy in eighteenth century mathematics. Early Science and Medicine, 9, 218-256. http://dx.doi.org/10.1163/1573382042176272

Guicciardini, N. (2004). Isaac Newton, Philosophiae Naturalis Principia Mathematica. In I. Grattan-Guinness (Ed.), Landmark Writings in Western Mathematics, Case Studies 1640-1940 (pp. 59-87). Amsterdam: Elsevier.

Hall, M. B. (1978). Newton and his theory of matter in the 18th century. Vistas in Astronomy, 22, 453-459. http://dx.doi.org/10.1016/0083-6656(78)90036-3

Hampson, N. (1981). The Enlightenment in France. In R. Porter, \& M. Teich (Eds.), The Enlightenment in National Context (pp 41-53). Cambridge: Cambridge University Press.

Hankins, T. L. (1990). Newton’s mathematical way a century after the Principia. In Durham, \& Purrington (Eds.), Some Truer Method (pp. 89-112). New York: Columbia University Press.

Harman, P. M. (1988). Newton to Maxwell: The Principia and British physics. Notes \& Records of the Royal Society of London, 42, 75-96.

Harrison, P. (1995). Newtonian science, miracles and the laws of nature. Journal of the History of Ideas, 56, 531-553. http://dx.doi.org/10.2307/2709991

Haycock, D. B. (2004). The long-lost truth: Sir Isaac Newton and the Newtonian pursuit of ancient knowledge. Studies in History and Philosophy of Science, Part A, 35, 605-623. http://dx.doi.org/10.1016/j.shpsa.2004.06.009

Heidarzadeh, T. (2006). The reception of Newton's theory of cometary tail formation. Centaurus, 48, 50-65. http://dx.doi.org/10.1111/j.1600-0498.2006.00036.x

Heimann, P. M., \& McGuire, J. E. (1971). Newtonian Forces and Lockean Powers: Concepts of matter in eighteenth century thought. Historical Studies in the Physical Sciences, 3, 233-306. http://dx.doi.org/10.2307/27757320

Henry, J. (1992). The scientific revolution in England. In R. Porter, \& M. Teich (Eds.), The scientific revolution in national context (pp. 178-209). New York-Cambridge. Cambridge University Press.

Hessen, B. (1931). The social and economic roots of Newton's Principia. In N. I. Bukharin (Ed.), Science at the Cross Roads. Papers Presented to the International Congress of the History of Science and Technology, 1931. London: The Delegates of the U.S.S.R. www.russelldale.com/phil-material/V1_Hessen.pdf

Hutton, S. (2004a). Emilie du Châtelet's Institutions de physique as a document in the history of French Newtonianism. Studies in History 
and Philosophy of Science, Part A, 35, 515-531.

http://dx.doi.org/10.1016/j.shpsa.2004.06.005

Hutton, S. (2004b). Women, science, and Newtonianism: Emilie du Châtelet versus Francesco Algarotti. In J. E. Force, \& S. Hutton (Eds.), Newton and Newtonianism: New studies (pp. 183-203). New York-Boston-Dordrecht-London-Moscow: Kluwer Academic Publishers.

Iliffe, R. (2004). Abstract considerations: Disciplines and the incoherence of Newton's natural philosophy. Studies in History and Philosophy of Science, Part A, 35, 427-454.

http://dx.doi.org/10.1016/j.shpsa.2004.06.004

Iltis, C. (1977). Madame du Châtelet's metaphysics and mechanics. Studies in History and Philosophy of Science, Part A, 8, 29-48. http://dx.doi.org/10.1016/0039-3681(77)90017-6

Jackson, M. W. (1994). A spectrum of belief: Goethe's 'Republic' versus Newtonian 'Despotism'. Social Studies of Science, 24, 673-701. http://dx.doi.org/10.1177/030631279402400403

Jacob, M. C. (1976). The Newtonians and the English Revolution 1687-1720. Ithaca, New York: Cornell University Press.

Jacob, M. C. (1977). Newtonianism and the origins of the Enlightenment: A reassessment. Eighteenth-Century Studies, 11, 1-25.

Jacob, M. C. (1978). Newtonian science and the radical enlightenment. Vistas in Astronomy, 22, 545-555.

http://dx.doi.org/10.1016/0083-6656(78)90046-6

Jacquier, F. (1755). Elementi di perspettiva, secondo $i$ principii di Brook Taylor con varie aggiunte spettanti all'ottica e alla geometria. Roma: Per generoso Salomoni.

Keill, J. (1701). Introductio ad veram physicam. Oxford: Sheldonian Theathre.

King-Hele, D. G., \& Rupert Hall, A. (1988). Newton's Principia and its legacy. [Proceedings of a Royal Society Discussion Meeting, 30, June 1987. London: The Royal Society of London, London]. Special Issue of the Notes \& Records of the Royal Society of London, 42, 1.

Koyré, A. (1965). Newtonian studies. Cambridge, MA: The Harvard University Press.

Le Seur, T., \& Jacquier, F. (1768). Elémens du calcul integral. 2 Vols. Parma: Monti.

Le Seur, T., Jacquier, F., \& Boscovich, G. R. (1743). Riflessioni de' Padri Tommaso Le Seur, Francesco Jacquier de el' Ordine de' Minimi, e Ruggiero Giuseppe Boscovich della Compagnia di Gesù Sopra alcune difficoltà spettanti i danni, e Risarcimenti della Cupola Di S. Pietro. Roma: Domenico Sante Santini.

Leshem, A. (2003). Newton on mathematics and spiritual purity. Dordrecht: Kluwer Academic Publishers.

Lord, F. H. (2000). Piety, politeness, and power: Formation of a Newtonian culture in New England, 1727-1779. Doctoral Dissertation, New Hampshire: University of New Hampshire [adviser: Jan Golinski].

Lüthy, C. (2000). What to do with seventeenth-century natural philosophy? A taxonomic problem. Perspectives on Science, 8, 164-195. http://dx.doi.org/10.1162/106361400568064

Lynn, M. R. (1997). Enlightenment in the republic of science: The popularization of natural philosophy in eighteenth-century Paris. Doctoral Dissertation, Madison, WI: The University of WiskonsinMadison [adviser: Domenico Sella].

Malet, A. (1990). Gregoire, Descartes, Kepler and the law of refraction. Archives Internationales d'Histoire des Sciences, 40, 278-304

Mandelbrote, S. (2004a). Newton and Newtonianism: An introduction. Studies in History and Philosophy of Science, Part A, 35, 415-425. http://dx.doi.org/10.1016/j.shpsa.2004.06.001

Mandelbrote, S. (2004b). Eighteenth-century reactions to Newton's anti-trinitarianism. In J. E. Force, \& S. Hutton (Eds.), Newton and Newtonianism: New studies (pp. 93-111). New York-Boston-Dordrecht-London-Moscow: Kluwer Academic Publishers

Marcialis, M. T. (1989). Francesco Algarotti’s worldly Newtonianism. Memorie della Società Astronomica Italiana, 60, 807-821.

Markley, R. (1999). Newton, Corruption, and the Tradition of Universal History. In J. E. Force, \& R. H. Popkin (Eds.), Newton and religion: Context, nature, and influence (pp. 121-143). Dordrecht: Kluwer Academic Publisher.

Mazzotti M (2004). Newton for ladies: Gentility, gender and radical culture. British Journal for the History of Science, 37, 119-146.
http://dx.doi.org/10.1017/S0007087404005400

McLaurin, C. ([1748] 1971). An account of Sir Isaac Newton's philosophical discoveries, in four books. New York: Georg Olms Verlag.

McMullin, E. (1978). Newton in matter and activity. Notre Dame, IN: University of Notre Dame Press.

Montgomery, S. L. (2000). Science in translation: Movements of knowledge through cultures and time. Chicago, IL: University of Chicago Press.

Munby, A. N. L. (1952). The distribution of the first edition of Newton's Principia. Notes and Records of the Royal Society, 10, 28-39.

Newton, (1713). Philosophiae naturalis principia mathematica. Editio secunda auctior et emendatior. Cambridge: Cornelius Crownfield.

Newton, (1714). Philosophiae naturalis principia mathematica. Editio secunda auctior et emendatior. Amsterdam: Sumptibus Societatis.

Newton, I. ([1713] 1729). The mathematical principles of natural philosophy. Translated by Motte Andrew. London: Motte B.

Newton, I. ([1726] [1739-1742], 1822). Philosophiae naturalis principia mathematica, auctore Isaaco Newtono, Eq. Aurato. Perpetuis commentariis illustrate, communi studio pp. Thomae le Seur et Francisci Jacquier ex Gallicana Minimorum Familia, matheseos professsorum. Editio nova, summa cura recemsita. A. et. Glasgow: J. Duncan.

Newton, I. (1687). Philosophiae naturalis principia mathematica. Imprimatur S. Pepys. Reg. Soc. Preses. Julii 5. 1686. Londini, Jussi Societatus Regiae ac Typis Josephi Streater. Prostat apud plures Bibliopolas. Anno MDCLXXXVII

Newton, I. (1726). Philosophiae naturalis principia mathematica. Editio tertia aucta et emendate. London: Guil. and Joh. Innys.

Newton, I. (1739-1742). Philosophiae naturalis principia mathematica, auctore Isaaco Newtono, Eq. Aurato. Perpetuis commentariis illustrate, communi studio pp. Thomae le Seur et Francisci Jacquier ex Gallicana Minimorum Familia, matheseos professorum. Geneva: Barillot et filii.

Newton, I. (1760). Philosophiae naturalis principia mathematica, auctore Isaaco Newtono, Eq. Aurato. Perpetuis commentariis illustrate, communi studio pp. Thomae le Seur et Francisci Jacquier ex Gallicana Minimorum Familia, matheseos professorum. Editio altera longe accuratior et emendatior. Geneva: Philibert.

Newton, I. (1972). Philosophiae naturalis principia mathematica. Harvard: The Harvard University Press.

Newton, I. (1999). The principia: Mathematical principles of natural philosophy. Translated by I. Bernard Cohen and Anne Whitman, assisted by Julia Budenz; preceded by 'A guide to Newton's Principia' by I. Bernard Cohen. Berkeley: University of California Press.

Osler, M. (2004). The new Newtonian scholarship and the fate of the scientific revolution. In J. E. Force, \& S. Hutton (Eds.), Newton and Newtonianism: New studies (pp. 1-13). New York-Boston-DordrechtLondon-Moscow: Kluwer Academic Publishers

Pagden, A. (1988). The reception of the 'New Philosophy' in eighteenth century Spain. Journal of the Warburg and Courtauld Institutes, 51, 126-140. http://dx.doi.org/10.2307/751266

Panza, M. (2003). Newton. Paris: Belles Lettres.

Pater C de (1994). Willem Jacob’s Gravesande (1688-1742) and Newton's Regulae Philosophandi, 1742. Lias: Sources and Documents Relating to the Early Modern History of Ideas, 21, 257-294.

Pemberton, H. (1728). A view of Sir Isaac Newton's philosophy. London: Palmer.

Pesic, P. (2003). Abel's Proof. An essay on the sources and meaning of mathematical unsolvability. Cambridge, MA: The MIT Press.

Phemister, P. (1993). Locke, sergeant, and scientific method. In T. Sorell (Ed.), The rise of Modern Philosophy: The tension between the new and traditional philosophies from Machiavelli to Leibniz (pp. 231-249). Oxford: Clarendon Press.

Phillipson, N. (1981). The Scottish Enlightenment. In R. Porter, \& M. Teich (Eds.), The enlightenment in national context (pp. 19-40). Cambridge: Cambridge University Press.

Pisano R., \& Capecchi D. (2014-Forthcoming) Tartaglia's science weights and Mechanics in XVI century. Selection from Quesiti et inventioni diverse: Books VII-VIII. Dordrecht: Springer.

Pisano, R. (2007). Brief history of centre of gravity theory. Epistemological notes. Proceedings of 2nd Proceedings of 3rd Conference of 


\section{P. BUSSOTTI, R. PISANO}

European Society for the history of science, Krakow: Poland Academy of Science, 934-941.

Pisano, R. (2011). Physics-mathematics relationship. Historical and epistemological notes. In E. Barbin, M. Kronfellner, \& C. Tzanakis (Eds.), Proceedings of the ESU 6 European Summer University History And Epistemology in Mathematics, Vienna: Verlag Holzhausen GmbH-Holzhausen Publishing Ltd., 457-472

Pisano, R. (2013). Reflections on the scientific conceptual streams in Leonardo da Vinci and his relationship with Luca Pacioli. Advances in Historical Studies, 2, 32-45.

http://dx.doi.org/10.4236/ahs.2013.22007

Pisano, R. (2013a-forthcoming). On the electromagnetic theory. Lagrangian mathematical conceptual streams in Maxwell's Physics Mathematics Relationship. Rio de Janeiro: Scientiarum Congress. Preprint.

Pisano, R. (2013b). Notes on the historical conceptual streams for mathematics and physics teaching. Pedagogika. In press.

Pisano, R. (2013c). On the principle of virtual laws and its framework in Lazare Carnot's mechanics. Submitted to Archive Internationales d'Histoire des Sciences.

Pisano, R., \& Bussotti, P. (2012). Galileo and Kepler: On theoremata circa centrum gravitatis solidorum and mysterium cosmographicum. History Research, 2, 110-145

Pisano, R., \& Bussotti, P. (2013). Notes on the concept of force in Kepler. In R. Pisano, D. Capecchi, \& A. Lukešová (Eds.), Physics, astronomy and engineering. Critical problems in the history of science and society. International 32nd Congress for the SISFA-Italian Society of Historians of Physics and Astronomy (pp. 337-344). Šiauliai: The Scientia Socialis UAB \& Scientific Methodical Centre Scientia Educologica Press, Lithuania.

Pisano, R., \& Capecchi, D. (2013). Conceptual and mathematical structures of mechanical science in the western civilization around 18th century. Almagest, in press.

Pisano, R., Capecchi, D., \& Lukešová, A. (2013). Physics, astronomy and engineering. Critical problems in the history of science and Society. International 32nd Congress for the SISFA-Italian Society of Historians of Physics and Astronomy. Šiauliai: The Scientia Socialis UAB \& Scientific Methodical Centre Scientia Educologica Press, Lithuania.

Porter, R. (1981). The Enlightenment in England. In R. Porter, \& M. Teich (Eds.), The Enlightenment in National Context (pp. 1-18). Cambridge: Cambridge University Press.

Porter, R., \& Teich, M. (1992). The scientific revolution in national context. New York, Cambridge: Cambridge University Press. http://dx.doi.org/10.1017/CBO9781139170215

Pulte, H., \& Mandelbrote, S. (2011). The reception of Isaac Newton in Europe. London: Continuum, Publishing Corporation.

Purrington, R. D., \& Durham, F. (1990). Newton's Legacy. In Durham and Prurrington (Eds.), Some Truer Method (pp. 1-13). New York: Columbia University Press.

Rattansi, P. M. (1981). Voltaire and the Enlightenment image of Newton. In H. Lloyd-Jones, V. Pearl, \& B. Worden (Eds.), History and imagination. Essays in honour of H. R. Trevor-Roper (pp. 218-231). New York: Holmes and Meier.

Rouse Ball, W. W. (1893, 1972). An essay on Newton's Principia. London: Macmillan.

Rousseau, G. S., \& Porter, R. (1980). The ferment of knowledge. Studies in the historiography of eighteenth century science. Cambridge: Cambridge University Press. http://dx.doi.org/10.1017/CBO9780511572982

Ruderman, D. (1997). On defining a Jewish stance toward Newtonianism: Eliakim ben Abraham Hart's Wars of the Lord. Science in Context, 10, 677-692. http://dx.doi.org/10.1017/S0269889700002866

Rupert Hall, A. (1999). Isaac Newton: Eighteenth-century perspectives. Oxford: Oxford University Press.

Schama, S. (1981). The Enlightenment in the Netherlands. In R. Porter, \& M. Teich (Eds.), The Enlightenment in National Context (pp. 5471). Cambridge: Cambridge University Press.

Schuster, J. A. (2000). Descartes opticien: The construction of the law of refraction and the manufacture of its physical rationales, 16181629. In S. Gaukroger, J. Schuster, \& J. Sutton (Eds.), Descartes' natural philosophy (pp. 258-312). London and New York: Rout- ledge.

Schuster, J. A. (2013). Descartes Agonistes: Physico-mathematics, method and corpuscular-mechanism 1618-1633. Dordrecht: Springer.

Shank, J. B. (2008). The Newton wars and the beginning of French Enlightenment. Chicago, IL: University of Chicago Press. http://dx.doi.org/10.7208/chicago/9780226749471.001.0001

Smolinski, R. (1999). The logic of millennial thought: Sir Isaac Newton among his contemporaries. In J. E. Force, \& R. H. Popkin (Eds.), Newton and religion: Context, nature, and influence (pp. 259-289). Dordrecht: Kluwer Academic Publisher.

Snobelen, S. (1997). Caution, conscience, and the Newtonian reformation: The public and private heresies of Newton, Clarke, and Whiston. Enlightenment and Dissent, 16, 151-184.

Snobelen, S. (1998). On Reading Isaac Newton's Principia in the 18th Century. Endeavour, 22, 159-163. http://dx.doi.org/10.1016/S0160-9327(98)01148-X

Snobelen, S. (2004). William Whiston, Isaac Newton and the crisis of publicity. Studies in History and Philosophy of Science, Part A, 35, 573-603. http://dx.doi.org/10.1016/j.shpsa.2004.06.008

Stewart, L. (1992). The rise of public science: Rhetoric, technology, and natural philosophy in Newtonian Britain, 1660-1750. Cambridge: Cambridge University Press.

Stewart, L. (2004). The trouble with Newton in the eighteenth century. J. E. Force, \& S. Hutton (Eds.), Newton and Newtonianism: New studies (pp. 221-238). New York-Boston-Dordrecht-London-Moscow: Kluwer Academic Publishers.

Taylor, S. S. B. (1981). The Enlightenment in Switzerland. In R. Porter, \& M. Teich (Eds.), The Enlightenment in National Context (pp. 72-89). Cambridge Cambridge University Press.

Teich, M. (1981). Bohemia: From darkness into light. In R. Porter, \& M. Teich (Eds.), The Enlightenment in National Context (pp. 141163). Cambridge: Cambridge University Press.

Thijssen, J. M. M. H. (1992). David Hume and John Keill and the structure of Continua. Journal of the History of Ideas, 53, 271-286. http://dx.doi.org/10.2307/2709874

Van der Wall, E. G. E. (2004). Newtonianism and religion in the Netherlands. Studies in History and Philosophy of Science, Part A, 35, 493-514.

Wallis, P. J., \& Wallis, R. (1977). Newton and Newtoniana, 1672-1975: A bibliography. Folkstone: Dawson.

Westfall, R. S. (1958). Science and religion in seventeenth century England. New Haven: Yale University Press.

Westfall, R. S. (1971). The construction of modern science: Mechanism and mechanic. New York: Wiley \& Sons Inc.

Westfall, R. S. (1983, 1995). Never at rest: A biography of Isaac Newton. Cambridge: Cambridge University Press.

Whaley, J. (1981). The Protestant Enlightenment in Germany. In R. Porter, \& M. Teich (Eds.), The enlightenment in national context (pp. 106-117). Cambridge: Cambridge University Press.

Whiston, W. (1707). Praelectiones astronomicae. Charkouiae: Typis Academicis.

Wigelsworth, J. R. (2003). Competing to popularize Newtonian philosophy: John Theophilus Desaguliers and the preservation of reputation. Isis, 94, 435-455. http://dx.doi.org/10.1086/380653

Wright, J. (1833). Commentary on Newton's Principia, with a supplementary volume. Designed for the use of students at the university. London: Tegg.

Yolton, J. (1994). Philosophy, religion and science in the seventeenth and eighteenth centuries. New York: University of Rochester Press. First published in 1990.

Young, B. (2004). Newtonianism and the enthusiasm of Enlightenment. Studies in History and Philosophy of Science, Part A, 35, 645-663. http://dx.doi.org/10.1016/j.shpsa.2004.06.011

Zambelli, P. (1978). Antonio Genovesi and 18th-century empiricism in Italy. Journal of the History of Philosophy, 16, 195-208. http://dx.doi.org/10.1353/hph.2008.0733

Zinsser, J. (2003). Essay Review: The ultimate commentary: A consideration of I. Bernard Cohen's Guide to Newton's Principia. Notes and Record of the Royal Society of London, 57, 231-238. http://dx.doi.org/10.1098/rsnr.2003.0208

Zinsser, J. P. (2001). Translating Newton's Principia: The Marquise du 


\section{P. BUSSOTTI, R. PISANO}

Châtelet's revisions and additions for a French audience. Notes and Records of the Royal Society of London, 55, 227-245. http://dx.doi.org/10.1098/rsnr.2001.0140 